\title{
Práticas de gestão e representações sociais do administrador: algum problema?
}

\author{
Management and social representation practices of the administrator: any problem?
}

\author{
Jacquelaine Florindo Borges ${ }^{1}$ \\ Cintia Rodrigues de Oliveira Medeiros ${ }^{2}$ \\ Tania Casado ${ }^{3}$
}

\section{Resumo}

Nós examinamos, neste artigo, as representações sociais de estudantes de graduação em administração para situações em que a ética e a competitividade estão presentes de forma paradoxal. O objetivo do estudo é identificar como o sentido construído pelos estudantes sobre o que é a administração, a organização e o papel do administrador os leva a um determinado posicionamento simbólico acerca deste paradoxo. Tal problemática é examinada à luz da Critical Management Education e da Teoria das Representações Sociais. Nosso estudo é de natureza qualitativa e utilizamos como procedimentos metodológicos o teste de associação de palavras, o completion test para a análise de cinco casos noticiados pela mídia escrita e televisiva e a construção de desenhos-tema. Os resultados evidenciam o posicionamento simbólico ambíguo e contraditório dos estudantes em relação ao papel do administrador e à prática de gestão adequada nas referidas situações.

Palavras-chave: Ética empresarial. Dilemas. Paradoxos. Representações sociais. Comportamento organizacional.

\begin{abstract}
In this article we examine the social representations of Brazilian graduate students of Business Administration regarding situations in which ethics and competitiveness are paradoxically present. The aim of this study is to identify how the meaning, constructed by students, of what Administration is, as well as an organization, and the role of the administrator leads them towards certain symbolic positions concerning this paradox. This problematization is examined by means of the Social Representation Theory, as well as by Critical Management Education. Our study is qualitative in nature, and
\end{abstract}

Artigo submetido em 17 de agosto de 2008 e aceito para publicação em 08 de julho de 2010.

1 Doutoranda em Administração pelo Programa de Pós-Graduação da Faculdade de Economia, Administração e Contabilidade da Universidade de São Paulo (PPGA/FEA/USP); Mestre em Administração pelo Programa de Pós-Graduação da Universidade Federal de Uberlândia (PPGA/UFU); Professora da Faculdade de Gestão e Negócios da Universidade Federal de Uberlândia (FAGEN/UFU). Endereço: Av. Mato Grosso, 1982, Bairro Brasil, CEP 38400-724, Uberlândia, Minas Gerais. E-mail: jacquelaine@usp.br

2 Doutoranda em Administração pelo Programa de Doutorado em Administração de Empresas da Escola de Administração de Empresas de São Paulo da Fundação Getúlio Vargas (EAESP/FGV); Mestre em Administração pelo Programa de Pós-Graduação da Universidade Federal de Uberlândia (PPGA/UFU); Professora da Faculdade de Gestão e Negócios da Universidade Federal de Uberlândia (FAGEN/UFU). Endereço: Alameda Antonio Scanapieco, 236, Jardim Karaiba, CEP 38411-196, Uberlândia, Minas Gerais. E-mail: cintia@fagen.ufu.br

${ }^{3}$ Psicóloga, Doutora e Mestre em Administração pela Universidade de São Paulo - USP; Professora e pesquisadora da Faculdade de Economia, Administração e Contabilidade da Universidade de São Paulo - FEA/USP. Endereço: Av. Prof. Luciano Gualberto, 908, E-120 - Cidade Universitária, CEP 05508-900, São Paulo, SP, Brasil. E-mail: tcasado@usp.br 
the methodological procedures used are: a word association test, a completion test for the analysis of five cases reported by the printed and televised media, and the construction of theme drawings. The results show that students have an ambiguous and contradictory symbolic position regarding not only the role of the administrator, but also the appropriate management practice in these situations.

Keywords: Business ethics. Dilemmas. Paradoxes. Social representations. Organizational behavior.

\section{Introdução}

Um dos principais desafios do trabalho do professor em cursos de graduação está no modo como ele participa do processo em que os estudantes constroem as representações sociais específicas da profissão. Para os estudantes que optaram por se graduar em Administração essas representações são construídas ao longo do curso, considerando: os conceitos discutidos, as ferramentas apreendidas, as conversas com os colegas, a prática como estagiário, as visitas técnicas às empresas, os eventos que a instituição de ensino oferece e as informações sobre a profissão que os estudantes obtêm em diferentes mídias. Os sentidos do que seja a administração, a organização e o papel do administrador vão se formando no decorrer do curso. Essa gama de significados se tornará parte da subjetividade do futuro administrador orientando o seu comportamento e a sua prática profissional. Neste estudo, nós adotamos como pressuposto que as representações sociais são portadoras de sentido e atuam como lentes que orientarão esses futuros administradores a assumirem determinado posicionamento em relação aos diversos paradoxos e dilemas que a profissão lhes apresentar.

Paradoxos e dilemas estão presentes em situações cotidianas vividas por gestores de diferentes organizações, no setor público, privado e não-governamental. O paradoxo revela a contradição ou a tensão entre elementos que, isoladamente, são vistos como lógicos, mas, quando estão simultaneamente presentes em uma situação, geram conflito e podem ser vistos como absurdos e irracionais, como, por exemplo, valores e crenças (CALTON e PAYNE, 2003 ; LEWIS, 2000). Já o dilema moral diz respeito à tensão presente na escolha do indivíduo entre beneficiar alguém (incluindo ele próprio), um grupo ou uma organização, e, com essa decisão, causar danos para a própria organização, outros indivíduos, grupos e organizações. Nesse caso, o gestor deve escolher entre satisfazer o interesse próprio ou da organização que ele dirige e os interesses dos outros (HOSMER, 1994 ; MALINOWSKI e BERGER, 1996; PRIEM e SAAFFER, 2001).

s organizações contemporâneas tornaram-se espaços potenciais para paradoxos e dilemas, pois espera-se dos gestores que eles sejam capazes de atribuir sentido, compreender e gerir sistemas contraditórios e ambíguos, constituídos por uma ampla variedade de elementos que se interrelacionam: expectativas, sentimentos, discursos, identidades, demandas, valores, interesses e práticas. Tais situações exigem dos gestores mais do que conhecimento técnico, elas requerem disposição e habilidade para agir de forma ética.

Na prática administrativa, a relação entre ética e competitividade é, muitas vezes, simplificada e permeada por mitos. Dentre eles, a ideia de que é simples ser ético: basta se afastar daquilo que "cheira mal". Outra ideia comum é a individualização dos problemas morais: atribuir o comportamento imoral em negócios tão somente a "algumas maçãs podres" e aceitar que a liderança ética depende basicamente da integridade dos líderes. Ou, ainda, gestores podem desenvolver uma crença ingênua em normalizações, como se a ética pudesse ser gerida exclusivamente a partir de programas e códigos formais de conduta (TREVIÑO e BROWN, 2004).

Nós examinamos, neste artigo, o posicionamento simbólico adotado por estudantes que estão concluindo o seu curso de graduação em Administração para situações em que a ética está subordinada à competitividade, identificando as representações sociais desses estudantes para a administração, a organização e o papel do administrador nessas situações. Para o desenvolvimento da pesquisa, utilizamos três técnicas projetivas: o 
teste de associação de palavras, o completion test para a análise de casos noticiados pela mídia brasileira escrita e televisiva e a construção de desenhos-tema.

O artigo está assim estruturado: inicialmente, examinamos o conceito de ética no campo empresarial e as críticas à práxis organizacional. Em seguida, examinamos as contribuições da Critical Management Education para a compreensão do papel dos administradores na construção da realidade, e, também, as contribuições da Teoria das Representações Sociais para a compreensão do papel das representações sociais no posicionamento simbólico dos gestores. Na sequência, nós apresentamos os procedimentos metodológicos, seguidos da descrição e análise dos dados do estudo. Em uma última seção, nós descrevemos as implicações da pesquisa e os limites do estudo.

\section{Subordinação da ética à competitividade: questionando a práxis organizacional}

A ocorrência de diversos escândalos corporativos no início dos anos 2000 gerou uma grave crise de confiança pública e chamou a atenção para o poder que as corporações adquiriram, suscitando mudanças no setor privado e no setor público. Governos de diversos países trabalharam para a aprovação de leis e normas mais rígidas visando evitar ou minimizar os impactos do que a mídia passou a chamar de "escândalos corporativos" ou "crimes corporativos" (MOKHIBER, 1995). A adoção de códigos de conduta corporativos foi uma das respostas das empresas para enfrentar a crise de confiança que se estabeleceu. $\mathrm{Na}$ academia, autores de diferentes matrizes teóricas que tinham, em comum, a premissa que uma transformação significativa deveria ocorrer no ensino de administração e na prática dos gestores, ampliaram o debate sobre a ética nos negócios. Adler (2002) e Giacalone e Thompson (2006) defendiam que era necessário questionar o que as escolas de negócios ensinavam aos seus estudantes a respeito de ética e de responsabilidade social. A seguir, nós discutimos as referências conceituais no campo da ética empresarial e as críticas às práticas corporativas que violam princípios éticos.

\section{A ética e os negócios}

O tema Ética desperta o interesse de estudiosos desde a antiguidade. Considerada uma das mais antigas disciplinas filosóficas, é geralmente definida como a ciência da conduta (ABBAGNANO, 1999). Não é nosso objetivo apresentar neste estudo uma revisão ampla e nem mesmo uma síntese da tradição multissecular de pesquisas no campo da ética. Resumidamente, destacamos que tanto na Antiguidade quanto no mundo moderno, duas concepções (ABBAGNANO, 1999) rivalizaram e se entremesclaram: (1) A Ética do fim - trata do ideal para o qual o homem se dirige com base em sua natureza racional e na busca do bem como realidade perfeita; e (2) a Ética da motivação - trata dos motivos da conduta humana ou das forças que a determinam, para isso, se atém ao conhecimento dos fatos e entende o bem como objeto de apetição.

A consciência moral dos indivíduos é uma espécie de voz interior, como afirma Vasquez (2005) que a descreve como um produto histórico-social marcado pela natureza das relações sociais dominantes de cada época e, por isso, muda de acordo com a natureza das relações entre indivíduos e sociedade. Essa consciência torna possível a avaliação moral dos indivíduos e também gera a obrigatoriedade moral. Em estudos contemporâneos sobre ética, as teorias da obrigatoriedade moral estão divididas em dois gêneros: (1) na concepção deontológica, a obrigatoriedade moral funda-se no dever e em princípios morais; e (2) na concepção teleológica, a obrigatoriedade do ato moral funda-se nas consequências do ato, tanto para $o$ próprio indivíduo que o pratica (egoísmo ético) quanto para o maior número de pessoas (utilitarismo). 
Nas organizações contemporâneas, diversos campos sensíveis e emergentes pedem a interferência da ética, especialmente aqueles que dizem respeito às relações das empresas com os diferentes públicos: direitos dos trabalhadores, questões de gênero, interesses das minorias, segurança e saúde no trabalho, meio ambiente, crimes corporativos, impactos sociais das estratégias empresariais (MELÉ, 2008). Também, espera-se que a ética na administração pública e na política seja capaz de romper com a tradição de escândalos e reverter o elevado índice de corrupção nos negócios públicos em países de tradição patrimonial (CARVALHO, 2004; JORNAL FOLHA DE S. PAULO, 2009).

A despeito dessa constatação de que a ética perpassa as relações entre os indivíduos, as organizações, a sociedade e o meio ambiente, essa não se constituiu um tema dos estudos clássicos de gestão. Apenas nas décadas de 60 e 70, o ensino de ética passa a ser praticado em faculdades de Administração e Negócios, principalmente nos Estados Unidos (ARRUDA, WHITAKER e RAMOS, 2001). Os estudos sobre a ética nos negócios estão, geralmente, divididos em duas áreas: a ética normativa, campo da filosofia moral e da teologia que orienta os indivíduos sobre como eles devem se comportar, e a ética descritiva ou empírica, campo da gestão e dos negócios que se interessa por explicar e predizer o comportamento atual dos indivíduos (O'FALLON e BUTTERFIELD, 2005). Possíveis colaborações entre os dois campos de pesquisas são examinadas por Schleidgen, Jungert e Bauer (2010).

As pesquisas no segundo campo vêm sendo edificadas sobre a Teoria do Desenvolvimento Moral (TDM), desenvolvida por psicólogos cognitivistas, inicialmente proposta por Jean Piaget, posteriormente por Lawrence Kohlberg, e, por seu aluno James Rest (MARNBURG, 2001). Kohlberg e Hersh (1977) afirmam que cada estágio é um conjunto estruturado ou um sistema organizado de pensamento, representando as transformações que ocorrem na forma ou na estrutura de pensamento de uma pessoa. A respeito do trabalho de Kohlberg (KOHLBERG e HERSH, 1977), Biaggio (1997) enfatiza a sequência universal de estágios do julgamento moral que ele postula e defende que a maturidade moral é atingida, quando o indivíduo transcende os valores da cultura em que ele foi socializado, ao invés de incorporá-los passivamente.

Resumidamente, são seis os estágios morais propostos por Kolberg (KOHLBERG e HERSH, 1977; BIAGGIO, 1997), agrupados em três níveis: pré-convencional (estágio um e dois), convencional (estágio três e quatro) e pós-convencional e da autonomia (estágios cinco e seis). O primeiro estágio caracteriza-se pela orientação para a punição e a obediência; nele, a moralidade de um ato é definida por suas consequências para o indivíduo. O segundo estágio caracteriza-se pelo hedonismo instrumental relativista; nele, uma ação moralmente correta é definida pelo grau de atendimento das necessidades da pessoa e, eventualmente, dos outros, e pelo prazer que proporcionam.

O terceiro estágio caracteriza-se pela moralidade do "bom garoto" e da "boa garota", da aprovação social e das relações interpessoais, sendo moralmente certo aquele comportamento que gera a aprovação dos outros e se conforma aos estereótipos. O quarto estágio caracteriza-se pela orientação para a lei e a ordem, para as normas e a autoridade estabelecida; nele, comportar-se de forma moralmente correta é cumprir o dever e as obrigações, mostrando respeito pela autoridade e mantendo uma dada ordem social para o seu próprio bem e segurança.

O quinto estágio caracteriza-se pela orientação para o contrato social democrático, para o relativismo dos valores e opiniões pessoais tendo em vista a busca pelo consenso. Comportar-se de modo moralmente correto é agir para definir os termos gerais dos direitos dos indivíduos e dos padrões sociais, os quais devem ser criticamente examinados e ampliados para o conjunto da sociedade. O sexto estágio caracteriza-se pela orientação para princípios éticos universais; nele, o indivíduo consciente reconhece os princípios morais abstratos e universais, tais como justiça, reciprocidade, igualdade, respeito pela dignidade da pessoa, e age de acordo com eles.

Marnburg (2001) discorda do pressuposto básico da teoria do desenvolvimento moral, ou seja, da existência de relação de causa e efeito entre julgamento moral, atitudes éticas e comportamento em processo de tomada de decisão. Ele também questiona a pressuposição básica da psicologia cognitiva de que pessoas agem de 
acordo com o melhor julgamento que fazem de uma situação. Ele lembra que pesquisadores têm falhado em seus esforços empíricos para explicar o comportamento pela habilidade de julgamento moral. Sob críticas, os estudos no campo da ética descritiva continuam a desenvolver modelos teóricos que descrevem e orientam o processo de decisão moral, por exemplo, o modelo contingencial de Jones (1991) e o modelo interacionista de Treviño (1986). Esses modelos, geralmente, consideram que o processo de tomada de decisão moral ocorre a partir de quatro passos (O'FALLON e BUTTERFIELD, 2005): (a) consciência moral (identificar e interpretar as situações e a natureza da questão moral); (b) julgamento moral (fazer o julgamento e decidir qual curso de ação é moralmente correto); (c) intenção moral (priorizar os valores morais sobre outros valores); e, (d) comportamento moral (executar e implementar a intenção moral).

Um número variado e crescente de pesquisadores tem, conforme O'Fallon e Butterfield (2005), proposto e testado uma ampla gama de variáveis que influenciam cada um desses quatro passos: fatores individuais (idade, educação, gênero, nacionalidade, religião, dentre outros), fatores organizacionais (competitividade, códigos de ética, cultura e clima ético, tipo de indústria, tamanho da organização, crises organizacionais, dentre outros) e a intensidade moral (percepção da magnitude das consequências da decisão e do comportamento) - Albaum e Peterson (2006), Calton e Payne (2003), Cristensen e Kohls (2003), Lewis (2000), Martynov (2009), Priem e Shaffer (2001), Treviño e Nelson (1995), Weber e Mcgivern (2010).

Treviño e Nelson (1995) argumentam que, nos negócios, pessoas em diferentes posições hierárquicas lidam todos os dias com questões que envolvem conflitos de valores e tomada de decisão acerca do que é certo e do que é errado; portanto, a ética nos negócios diz respeito ao comportamento. A questão, porém, é que as pessoas são socializadas para aceitar diferentes comportamentos dependendo do contexto, e, além disso, os indivíduos têm diferentes selfs e desempenham diferentes papéis. Para as referidas autoras, o debate sobre ética e responsabilidade dos gestores deve, necessariamente, abordar o ser humano de modo integral. Isso significa juntar todos os selfs: ser igualmente ético em casa (family self), no escritório (office self) e na religião (religious self), por exemplo.

Todavia, Treviño e Nelson não consideram que esses múltiplos selfs e papéis possam estar na raiz de muitos problemas éticos. As autoras definem que o comportamento ético nos negócios é aquele consistente com os princípios, as normas e os padrões das práticas de negócios acordadas com a sociedade. Ainda, "os vários dilemas éticos nos negócios são totalmente previsíveis" (TREVIÑO e NELSON, 1995, p. 47), e "os gestores necessitam de ferramentas práticas e simples para gerir condutas éticas" (p. 143). Ao enfatizarem os aspectos cognitivos de decisões éticas, Treviño e Nelson dirigem pouca atenção para outros aspectos também presentes em processos de tomada de decisão ética: as relações assimétricas de poder que dão origem ao acordo que define quais as práticas de negócios são éticas em uma sociedade; a ambiguidade advinda da pluralidade dos fins em uma única situação; ou, ainda, à complexa relação entre motivos, fins, meios, resultados e consequências do ato moral em situações que se caracterizam por sua novidade, singularidade e imprevisibilidade.

\section{Críticas às práticas de gestão}

No final do século XX e começo do século XXI, o sentimento anticorporação emergiu em diferentes lugares do mundo (KLEIN, 2002) e tornou-se parte da agenda de movimentos sociais e tema constante na mídia. No cinema, desde os anos 80, a denúncia de situações em que o comportamento organizacional e/ou o comportamento dos gestores não coincidem com os valores da sociedade contemporânea esteve presente em diversos filmes e documentários, dentre eles, Wall Street: poder e cobiça (1987), Roger e Eu (1989), Roda da fortuna (1994), The corporation (2003), Super size me (2004), O que você faria? (2005), Enron: os mais espertos da sala (2005). Na mídia impressa, livros como Crimes corporativos (MOKHIBER, 1995) e Sem Logo (KLEIN, 2002) e matérias e fóruns de discussão em jornais como New York Times (2010) e Financial Times (2010), também confirmam esse sentimento anti-corporação. 
Tais fatos ensejaram a reflexão em uma das mais tradicionais escolas de negócios do mundo, a Harvard Business School (HBS), sobre o papel que desempenha no sistema educacional norte-americano e mundial. Sob o título How To Fix Business School, a Harvard Business Review (HBR) abriu um fórum online para promover o diálogo entre especialistas, executivos, estudantes e leitores, durante cinco semanas, nos meses de abril a maio de 2009. Um dos objetivos do fórum, em andamento até o momento desta pesquisa, é (re)discutir a responsabilidade das escolas de negócios em eventos que marcaram as últimas décadas: escândalos corporativos e crise financeira (HBR, 2010a). Os resultados do debate estão postados em blog institucional sob o título de What We've Learned from the MBA Debate (HBR, 2010b). Uma das questões de destaque desse debate avalia se a crise econômica foi o resultado das ações de alguns executivos não éticos, ou se ela foi causada por algo de natureza sistêmica presente na educação que esses executivos receberam.

Nas últimas décadas, diversos autores questionaram como está sendo preparada esta nova geração de business practitioners, aquela que ocupará posições-chave na hierarquia das organizações do setor público e privado. Para Mintzberg (2007), os gestores se engajaram na busca por um tipo de produtividade que é altamente nociva, porque causa danos ao meio ambiente, porque trata as pessoas como recursos e porque busca resultado de curto prazo, ao invés de resultados sustentáveis de longo prazo.

A visão instrumental e racionalizante que caracteriza o modelo de gestão predominante na sociedade contemporânea transcende o espaço organizacional e está presente nas relações sociais em geral. Chanlat (2000) denomina managerialismo o sistema de descrição, de explicação e de interpretação do mundo a partir das categorias da gestão. Esse sistema não apenas separa o econômico do social, mas faz do primeiro o parâmetro que orienta a tomada de decisão dos gestores: a obsessão pela eficácia medida quase que exclusivamente por indicadores quantitativos e financeiros; por indicadores de desempenho e produtividade cada vez mais elevados; por métodos que produzem resultados no curto prazo; e por técnicas de controle manipuladoras e fragmentadoras do ser humano. Os caminhos para superar a distância entre o pensamento econômico e as questões sociais no mundo dos negócios são, conforme esse autor, a abertura disciplinar e o retorno de várias dimensões esquecidas pelo mundo da gestão: as dimensões fundamentais - humanas e sociais, o ator e o sujeito, a afetividade, a experiência vivida, o simbólico, a história e a ética.

Teorias que não consideram quaisquer comparações entre o que é certo ou errado são propagadas, ideologicamente, nas escolas de negócios, conforme Ghoshal (2005, p. 76), o que despoja os estudantes de qualquer senso de responsabilidade moral. Dentre as teorias que esse autor aborda estão: a análise das forças da indústria, a teoria da agência e a teoria dos custos de transação. Goshal (2005) afirma que é necessário questionar as pressuposições dessas teorias sobre as pessoas e as instituições. É preciso questionar por que o trabalhador é visto pelo mainstream das teorias de gestão como menos importante que o capital financeiro dos acionistas. Questionar o determinismo de forças externas que acabam por servir de justificativa para as ações de $C E O s$, quando esses justificam suas decisões e ações como reação a estas forças. Afinal, essa é uma forma de desumanização das práticas de gestão, pois "forças competitivas" ou "forças do mercado" são tratadas como entes autônomos de decisões humanas.

É necessário, ainda segundo Ghoshal (2005), questionar o porquê, apesar do senso comum e de evidências empíricas sugerirem o contrário, o modelo pessimista de pessoas como seres puramente autointeressados permanece dominando as teorias de gestão mencionadas anteriormente. Pfeffer (2005), ao discutir o trabalho de Ghoshal (2005), ressalta que, se as teorias de gestão são "harmful" ou "bad" para a prática, é porque o estudo empírico dos processos pelos quais ocorrem a dominação ou a substituição de teorias persiste como uma tarefa a ser realizada. Ele propõe que a ciência das organizações trate desses processos, sobretudo, como processos políticos.

Para Grit (2004), a complexidade do papel do administrador na busca de satisfação dos interesses de diversos públicos, ao mesmo tempo e, muitas vezes, divergentes, geram tensões difíceis de administrar. Estas tensões levam ao que Bird e Waters (1989) descreveram como "a moral muda" dos administradores, ou seja, estes evitam falar sobre questões morais para evitar confrontos e manter a harmonia nas relações entre os diversos públicos. Bird e Waters (2001), todavia, alertam que o silêncio também tem consequências: a banalização do 
abuso e o declínio da autoridade dos padrões morais estabelecidos. A conciliação de interesses dos diferentes stakeholders não parece ser fácil ou simples de administrar, pois não se trata apenas de diferentes expectativas quanto aos resultados, mas, também, de conflitos em relação a valores (WATERS, BIRD e CHANT, 1986).

Em pesquisa realizada com estudantes graduados em business ou escolas de negócios, e com estudantes graduados em outras áreas, McCabe, Butterfield e Treviño (2006) confirmam uma das hipóteses de sua pesquisa: estudantes graduados em escolas de negócios admitiram mais vezes (56\%) que trapacearam em relação àqueles não-graduados em negócios (47\%). Dentre os comportamentos encontrados no cotidiano escolar estão a trapaça ou a fraude em testes ou exames e outros relacionados à realização de trabalho escrito. A competição entre os estudantes, a possibilidade de não ser punido e a crença de que os colegas são desonestos geram esta "flexibilidade moral" que orienta o comportamento dos estudantes das escolas de negócios.

Os resultados de estudos realizados por Faria (2007, p. 168) evidenciam que a busca por competitividade no mundo corporativo justifica "outras práticas éticas e morais que não aquelas que devem ser observadas nas relações sociais". Competição e eficácia estão acima da valorização do sujeito e dos valores democráticos vigentes na sociedade. Ele identificou uma lacuna entre "o que deve ser" e o que de "fato é" no mundo corporativo. Como se, para ser competitivo, segundo a lógica de mercado, o gestor pudesse seguir uma "outra moral" e devesse ser julgado por critérios diferentes daqueles válidos para a sociedade em geral.

Por fim, ressaltamos que o paradoxo da subordinação da ética à competitividade não se apresenta apenas em nível micro ou individual. No campo sociológico, Sennett (2007) afirma que o "capitalismo flexível" e a cultura que desse emana conduzem ao enfraquecimento de valores como lealdade, confiança e compromisso. Em um contexto no qual prevalece o discurso da flexibilidade, predomina um tipo de indivíduo voltado para o curto prazo que Sennett (2007) denomina de "homem irônico"; homens e mulheres conscientes do elevado grau de contingência e fragilidade de seus "eus" e dos contextos em que estão inseridos. Esses indivíduos orientam o seu comportamento pela seguinte máxima: "Não deixe que nada grude em você" (SENNETT, 2007, p. 92).

A capacidade adaptativa dos indivíduos na organização contemporânea também foi objeto de estudo de Caldas e Tonelli (2000). Eles avaliam que esses indivíduos apresentam características do chamado "homemcamaleão". Uma nova personalidade que se move mais pela reação, apresentando comportamento mimético que imita as "personalidades" mais valorizadas. Este indivíduo tende a ser mais submisso ao lidar com a incerteza no ambiente organizacional e é dominado pela ansiedade. Ele tem propensão a seguir tendências e experimentar novidades e técnicas da moda. Wood Jr. e Paes de Paula (2001) afirmam que a recorrência às "fórmulas prontas" e a busca pelo sucesso tendem a afastar os gestores de processos criativos e de reflexão, para conduzi-los à constituição do "indivíduo S.A.”.

\section{A responsabilidade dos gestores na construção da realidade: contribuições da Critical Management Education (CME)}

A CME vem se constituindo em um campo de estudos, desde os anos 1990. Perriton (2007) apresenta o desenvolvimento da literatura produzida nesse campo no período de 1995 a 2005, nos EUA e Reino Unido. A CME se opõe à orientação gerencialista das escolas de negócios e seus pressupostos de racionalidade, eficiência, performance, controle e objetividade. Em contrapartida, propõe que a educação sobre gestão seja mais inclusiva em relação à variedade de vozes dos stakeholders e uma miríade de temas, como meio ambiente, trabalho, comunidade, multiculturalismo, diversidade racial/étnica e preocupação social (BOJE e AL-ARKOUBI, 2009). Os estudos no campo da CME têm sido influenciados pela Teoria Crítica (escola de 
Frankfurt), a Pedagogia Crítica na perspectiva de Paulo Freire e a ascenção dos Estudos Críticos de Gestão. As relações entre esses campos são examinadas por Boje e Al-Arkoubi (2009).

Para a pedagogia crítica freiriana, é necessária a desmistificação de que a escola "é um local sagrado, onde apenas se estuda e estudar não tem nada que ver com o que se passa no mundo lá fora" (FREIRE, 1992, p.44). Ao contrário de uma pedagogia reprodutora, na qual o estudante é socializado pelo capital, Freire (1970) propõe a pedagogia da autonomia rumo à transformação. A pedagogia crítica defende o compromisso do profissional com a sociedade. Para Freire (1983, p.16), o compromisso envolve decisão lúcida e profunda de quem o assume. O ser capaz de assumir um compromisso é aquele capaz de agir e refletir, "é preciso que seja capaz de, estando no mundo, saber-se nele". Portanto, não se aplica a um ser imerso no mundo, adaptado a ele e sem dele ter consciência, sem possibilidade de refletir sobre si e suas ações. O ser que está imerso na realidade, da qual não pode sair, nem "distanciar-se" para admirá-la e, assim, transformá-la, é um ser ahistórico, fora de seu tempo, já que, para tal ser, o tempo "seria" um eterno presente.

Na concepção freiriana, quando impedidos de atuação-reflexão, os homens encontram-se profundamente feridos em si mesmos, como seres de compromisso com o mundo, que deve ser humanizado para a humanização dos homens. O compromisso, próprio da existência humana, só existe no engajamento com a realidade, com os homens concretos que nela e com ela estão, e na solidariedade com aqueles que, na situação concreta, se encontram convertidos em "coisas". Assim, o compromisso do profissional com a sociedade implica tanto o compromisso genérico de um ser em um contexto histórico-social, quanto o compromisso com a profissão. Por ser inspirada na autonomia, a pedagogia crítica defende que as transformações necessárias rumo a uma ordem social mais igualitária deve ser pautada pela ética e a responsabilidade dos sujeitos na construção da realidade (CURRIE e KNIGHT, 2003; DE PAULA e RODRIGUES, 2006; McLAREN, MARTIN, FARAHMANDPUR et al., 2004; SAMRA-FREDERICKS, 2003).

Desse modo, a pedagogia crítica coloca questões desafiadoras no âmbito da CME, especialmente aquelas que tratam das transformações nas relações de poder, visto que é a partir delas que indivíduos e subjetividades têm existência. Fenwick (2005) explora três questões, tidas como cruciais, que devem ser consideradas por educadores no ensino de administração, de modo a assegurar aos estudantes uma educação crítico-reflexiva. A primeira questão da CME trata do posicionamento do educador crítico. O desafio é evitar que a imposição de uma postura crítica dê origem a uma nova hegemonia, ou crie uma "polaridade" entre a crítica acadêmica e a ortodoxia da prática do mundo real.

O segundo desafio da CME trata da fragmentação das subjetividades dos estudantes, diz respeito às aspirações daqueles em assumir posições privilegiadas dentro das organizações. A despeito das diferenças entre eles, a maioria dos estudantes de administração deseja ocupar uma posição de administrador, e não se engajar em denúncias anticorporação ou liderar transformações sociais revolucionárias que os levariam a se questionarem: "Mas, como, agora, eu posso trabalhar (nas corporações contemporâneas)?" (FENWICK, 2005, p. 35). Ao estimular o engajamento destes estudantes em críticas que atacam suas posições dominantes (tipicamente de classe média, por exemplo, branco, sexo masculino, não portador de deficiência física e heterossexual) sem habilitá-los a construir alternativas de posicionamento subjetivo, corre-se o risco de ter a alienação e a desilusão como o resultado da mudança cultural. Ainda, podem se desenvolver nos estudantes subjetividades híbridas, combinando uma posição de engajamento para a transformação social com uma posição de defesa dos interesses das empresas, levando à "compartimentalização da moral".

O terceiro desafio da CME refere-se às contradições entre as práticas administrativas e o pensamento crítico. É necessário o desenvolvimento de mais estudos e respostas para as situações que ocorrem em um contexto de alta competitividade, no qual as empresas pressionam supervisores a punir aqueles que não agem conforme os valores e procedimentos estabelecidos (FENWICK, 2005). Como resultado, os estudantes que não se deixam dominar pelas noções de estratégia, competência e controle podem não encontrar uma posição valorizada nas estruturas existentes na sociedade contemporânea. Sobre essa terceira questão, Cunliffe (2002) demonstrou a mesma preocupação, ao analisar a necessidade de incorporar a pedagogia crítica no 
ensino de administração e a construção de oportunidades reflexivo-dialógicas para a aprendizagem como um caminho em direção à formação de profissionais mais críticos e responsáveis.

Enfim, para Mingers (2000), ser crítico em administração envolve quatro dimensões de questionamento: (1) o ceticismo da retórica (questionamento dos aspectos lógicos dos argumentos, da linguagem utilizada, da validade de premissas e pressupostos); (2) a crítica da tradição (questionamento dos costumes e do modo como as coisas são feitas - taken for granted); (3) a crítica da autoridade (rejeição de uma visão dominante e aceitação de diferentes, mas válidas perspectivas); e, (4) a crítica da objetividade (reconhecimento de que conhecimento e informação não são objetivos e nem isentos de valor, e, além disso, são baseados no poder).

As dimensões da criticalidade da CME propostas por Mingers (2000) foram adaptadas e ampliadas por Boje e Al-Arkoubi (2009), que as denominam de pressuposições da criticalidade. Esses últimos propõem a ampliação da retórica pela inclusão do conceito de discurso (desconstrução e reconstrução de textos e falas) e, ao invés de autoridade, defendem o conceito de poder (polifonia ou múltiplas vozes, e polissemia ou diferentes significados e perspectivas). Eles adicionam outras duas dimensões da criticalidade: (5) reflexividade (ser crítico em relação a si mesmo como forma de desenvolver uma consciência de si como indivíduo, nos níveis relacional e coletivo, e desenvolver um self, que terá sempre um papel-chave no crescimento e transformação do indivíduo); e (6) realidade (questionar a realidade em que a educação ocorre e os fatores estruturais que influenciam o contexto educacional geral).

Além disso, Boje e Al-Arkoubi (2009) oferecem cinco princípios para a CME: capacidade ética de resposta, compromisso com a emancipação, promoção do multiculturalismo, desafio de dicotomias e fronteiras (coração, mente e espírito) e compartilhamento e descentralização do poder. Para esses autores, o modelo educacional dominante enfatiza a atividade cerebral, a racionalidade e o pensamento lógico; ao mesmo tempo, as emoções são vistas como fraquezas; a religião e a espiritualidade, como inaceitáveis.

\section{O papel das representações sociais no posicionamento simbólico dos gestores}

O conceito de representações sociais, formulado inicialmente por Moscovici em 1961, possibilitou o desenvolvimento de um campo de estudos que Farr (1996) classifica como uma forma sociológica de Psicologia Social. Moscovici (1976) desenvolve o conceito de representações sociais a partir da ideia de representações coletivas de Durkheim, e propõe que a realidade social é tanto física como imaginária. O que significa que os sujeitos representam os fatos de acordo com as circunstâncias contextuais e cotidianas, eles existem como parte de uma "rede social" e, individual e coletivamente, criam representações para se expressarem e agirem (MOSCOVICI, 1976).

Para Bauer e Gaskell (1999) e Voelklein e Howarth (2005), as representações sociais são construtos produzidos por grupos sociais e comunidades, ou seja, são criadas e validadas em processos de comunicação e interações sociais, nos quais os indivíduos participam ativamente. Conforme Farr (1998), uma representação é social, se está em duas ou mais mentes, nunca em apenas uma. Um indivíduo não cria representações isoladamente, pois são pessoas e grupos que criam representações no decurso da comunicação e da cooperação.

As representações sociais referem-se tanto ao processo em que as representações são elaboradas quanto às estruturas de conhecimento que são estabelecidas a partir delas (DUVEEN, 2007). Para Moscovici (2007), é por meio dos intercâmbios comunicativos que as representações sociais são estruturadas e transformadas. Conforme Jodelet (2001), elas circulam nos discursos, estão veiculadas em mensagens e imagens midiáticas e cristalizadas em condutas individuais e nas organizações. Para essa autora, as representações sociais são importantes na vida cotidiana, pois elas guiam as pessoas "no modo de nomear e definir conjuntamente os diferentes aspectos da realidade diária, no modo de interpretar esses aspectos, tomar decisões e, eventualmente, posicionar-se frente a eles de forma defensiva" (JODELET, 2001, p. 17). 
As representações sociais têm duas funções, conforme Moscovici (2007): a ancoragem e a objetivação. Na primeira função, elas convencionalizam, isto é, dão forma definitiva aos objetos, pessoas ou acontecimentos, dão uma identidade social ao que não estava identificado. Estes passam a ser localizados em uma determinada categoria, o que não significa simplesmente rotular, pois o objetivo principal é facilitar a interpretação, compreensão e formar opiniões. Mesmo enquanto objetos, pessoas e acontecimentos não se encaixam no modelo, é preciso fazê-lo entrar em uma categoria sob pena de não ser decodificado ou compreendido. Moscovici (2007) denomina ancoragem o processo de classificar e dar nomes.

Em sua segunda função, as representações sociais são prescritivas, pois se impõem sobre os indivíduos e grupos com força irresistível. Essa força é a "combinação de uma estrutura que está presente antes mesmo que nós comecemos a pensar e de uma tradição que decreta o que deve ser pensado" (MOSCOVICI, 2007, p. 36). Desse modo, como respostas prontas para todas as questões e por serem partilhadas por tantas pessoas, as representações pré-existentes penetram e influenciam a mente de cada indivíduo que já não as pensa, mas (re) pensa, (re) cita e (re) apresenta.

Todavia, as representações também podem ser inovadoras, se conduzidas por novas experiências, percepções e manifestações que não foram experimentadas anteriormente, e, ainda, por transformações que geram novos conteúdos e objetos. O processo associado a essa função das representações sociais é a objetivação ou a concretização e a "verdadeira essência da realidade" (MOSCOVICI, 2007, p. 71). Para Jodelet (2001), a representação social tem uma relação de simbolização com o seu objeto (substituindo-o) e de interpretação (ao lhe conferir significado). Desse modo, elas influenciam a eficácia social, porque ela orienta o sujeito a agir sobre o mundo e o outro, possibilitando o ajustamento prático do sujeito ao seu meio e o estabelecimento de um compromisso psicossocial.

Na concepção de representações sociais de Moscovici (2007), a comunicação de pensamentos e ideias é a base para a constituição de uma sociedade pensante em que as pessoas não são receptores passivos. Para o autor, a todo instante, é possível encontrar nas ruas, bares, escritórios e em outros lugares, pessoas analisando, comentando, julgando, formulando e expondo ideias que terão impacto decisivo em suas escolhas, planos e relações sociais. Desse modo, as representações sociais resultam da articulação entre o individual e o social, envolvendo cognição, emoção e cultura. As representações de indivíduos e grupos influenciam o posicionamento desses em relação às situações e objetos, e, também, o modo como eles interveem no contexto concreto em que vivem e na maneira como contribuem para a construção social da realidade.

Nos últimos anos, é possível identificar o crescente interesse da pesquisa nacional em administração pelo tema. A relação entre as representações sociais de profissionais da área da saúde e trabalhadores da indústria da panificação e suas práticas profissionais é analisada por Schwingel e Cavedon (2004) e Cavedon e Pires (2006), respectivamente. Cavedon e Ferraz (2005) e Carrieri, Leite da Silva e Junquilho (2008) analisam como as representações sociais dos gestores influenciam a prática estratégica. Esses estudos mostram que os pressupostos da teoria das representações sociais podem contribuir com uma compreensão mais ampla da formação profissional. No caso do presente estudo, a dinâmica da produção do conhecimento em administração ocorre por meio de diversos níveis de interação entre o estudante, as empresas, os professores, a literatura acadêmica, os textos de negócios/consultores, a mídia, as universidades e as escolas de negócios. A seguir, nós examinamos como a dinâmica dessas interações e processos comunicativos levam o estudante a desenvolver representações acerca da administração, do papel do administrador e do uso de práticas de gestão.

\section{Procedimentos Metodológicos}

No desenho desta pesquisa, de natureza qualitativa, nós utilizamos três técnicas projetivas para identificar as construções ou representações relacionais dos estudantes de administração acerca da administração, da 
organização e do papel do administrador, face às decisões a serem tomadas diante do paradoxo: subordinação da ética à competitividade. Inicialmente restritas à psicologia social (LILIENFELD, WOOD e GARB, 2000), as técnicas projetivas são utilizadas amplamente em pesquisas na área de marketing (FRAM e CIBOTTI, 1991; RAMSEY, IBBOTSON, BELL et al., 2004; BODY, 2005) e em educação (CATTERALL e IBBOTSON, 2000) por suas possibilidades de capturar a expressão de pensamentos e sentimentos difíceis de serem acessados por meio de questionários diretos e técnicas objetivas (CATTERALL e IBBOTSON, 2000; KEARNEY e HYLE, 2004; MEYER, 1991; RAMSEY, IBBOTSON, BELL et al., 2004; VINCE e BROUSSINE, 1996). No Brasil, alternativas de ensino-aprendizagem em administração têm sido experimentadas por diversos pesquisadores, incluindo a produção de desenhos (DAVEL, VERGARA e GHADIRI, 2007)

O presente estudo foi realizado com 27 estudantes do $7^{\circ}$ e $8^{\circ}$ períodos do curso de Administração de uma instituição de ensino superior privada, que cursavam a disciplina "Estratégias Corporativas" no segundo semestre de 2007. As etapas do estudo foram desenvolvidas como forma de avaliar a contribuição da disciplina para a formação destes estudantes. Durante a realização do estudo, estruturado em três etapas, descritas a seguir, os estudantes não precisavam se identificar e lhes foi solicitada a assinatura de um termo de consentimento.

Na primeira etapa do estudo, nós utilizamos o teste de associação de palavras. Cada estudante recebeu uma folha de papel sulfite e solicitamos que, individualmente, fizesse a associação de três palavras para cada uma das quatro palavras indutoras: competitividade, administrador, organização e ética organizacional. $\mathrm{O}$ teste de associação de palavras é apropriado para o estudo dos estereótipos sociais espontaneamente compartilhados pelos membros de um grupo, como aqueles relativos a uma profissão (BARDIN, 1988).

Na segunda etapa, utilizamos a técnica denominada completion test (RAMSEY, IBBOTSON, BELL et al., 2004). Separamos os estudantes em 6 grupos: dois grupos com 4 estudantes e um grupo com três, no $7^{\circ}$ período; e, no $8^{\circ}$ período, dois grupos com 4 estudantes e um grupo com 6 . Nesta etapa, dois estudantes do $8^{\circ}$ período não puderam participar. A técnica completion test, conforme Ramsey, tiveram na mídia brasileira, escrita e televisiva; (b) por se tratarem de temas recentes; (c) por envolverem o paradoxo subordinação da ética à competitividade; e, (d) pela necessidade de um encaminhamento reflexivo do profissional de administração acerca do tema.

Na terceira e última etapa deste estudo, nós trabalhamos com a técnica de construção de desenhos-tema, na forma semiestruturada. Conforme Van Kolck (1968), a técnica consiste na personificação de sentimentos e necessidades acerca do tema explorado, propiciando aos pesquisadores a interpretação das palavras e gravuras sobre a subjetividade ou o "modo de ver" dos participantes. Nesta etapa, mantivemos a formação dos grupos e distribuímos material como tesoura, papel em branco, revistas e jornais para recortes, pincéis, cola e papel flip chart. Solicitamos aos estudantes que produzissem uma ilustração que representasse o paradoxo "subordinação da ética à competividade", na forma de colagem, e, em seguida, elaborassem um texto explicativo sobre a mesma.

\section{Descrição e análise dos resultados: primeira fase da pesquisa}

Na primeira etapa, nós conduzimos um teste de associação de palavras. Esse foi o primeiro contato com o imaginário dos estudantes acerca do paradoxo "subordinação da ética à competitividade". Nós entendemos que por tratar-se de estudantes que estão nos últimos períodos do curso, esses já desenvolveram algum significado para as palavras indutoras. E, à medida que constroem determinada representação social (MOSCOVICI, 2000; JODELET, 2001) daquele paradoxo, esses estudantes passam a adotar determinada posição simbólica em relação ao mesmo, como orientação para suas práticas como futuros gestores. 
Tabela 1

Palavras induzidas por categoria

\begin{tabular}{|l|c|c|c|c|}
\hline \multirow{2}{*}{ Categorias } & \multicolumn{4}{c|}{ Palavras indutoras } \\
\cline { 2 - 5 } & Competitividade & Administrador & Organização & $\begin{array}{c}\text { Ética } \\
\text { organizacional }\end{array}$ \\
\cline { 2 - 5 } & $\begin{array}{c}\mathrm{F}^{*} \text { de palavras } \\
\text { induzidas }\end{array}$ & $\begin{array}{c}\mathrm{F}^{*} \text { de palavras } \\
\text { induzidas }\end{array}$ & $\begin{array}{c}\mathrm{F}^{*} \text { de palavras } \\
\text { induzidas }\end{array}$ & $\begin{array}{c}\mathrm{F}^{*} \text { de palavras } \\
\text { induzidas }\end{array}$ \\
\hline Ferramenta & 14 & 07 & 19 & 08 \\
\hline Característica moral & 05 & 12 & 09 & 16 \\
Competência & 18 & 53 & 19 & 09 \\
\hline Consequências & 19 & 04 & 14 & 19 \\
\hline Contexto & 25 & 04 & 0 & 01 \\
\hline Palavras descartadas & 0 & 01 & 81 & 81 \\
\hline Total de respostas & 81 & 81 & 74 & 71 \\
\hline $\begin{array}{l}\text { Total de palavras } \\
\text { induzidas }\end{array}$ & 55 & 63 & & 20 \\
\hline
\end{tabular}

Fonte: Elaborada pelas autoras

Nota: Frequência das associações por categoria

Os resultados apresentados na Tabela 1 mostram grande variedade de associações nas respostas dos estudantes. De um total de 263 palavras induzidas para 4 palavras indutoras, $225(85,55 \%)$ foram citadas apenas uma vez. Os estudantes usam grande variedade de palavras para expressar o significado que as palavras indutoras provocam neles, o que pode indicar a dificuldade de construir uma referência comum acerca de cada palavra indutora. Para examinar esta questão buscamos extrair categorias do conjunto de palavras induzidas (BARDIN, 1988).

Após a análise descritiva do conteúdo, buscando representações condensadas, bem como representações explicativas, nós agrupamos as palavras induzidas em cinco categorias, conforme Tabela 1: (1) ferramenta ("o que se utiliza"); (2) característica moral; (3) competência; (4) consequências; (5) contexto (social, político, econômico). No processo de categorização, duas palavras foram descartadas por não apresentarem associação com nenhuma das categorias elegidas.

Os estudantes associaram a palavra indutora competitividade, principalmente, com palavras que tratam do contexto de atuação da organização (25 vezes): clientes, concorrentes, mercado. Os estudantes também associaram competitividade com palavras que significavam a natureza desse contexto: guerra, disputa e batalha. Em seguida, o maior número (19) de associações encontrado foi com as consequências da competitividade: diferenciação, eficácia, enfoque. O terceiro aspecto mais frequentemente lembrado pelos estudantes foram as competências necessárias para tornar uma organização competitiva: certeza, experiência, 
flexibilidade e "garra". Esse resultado nos chama a atenção, pois as características morais para ser competitivo são pouco lembradas: somente 5 palavras, dentre elas, humildade, companheirismo e responsabilidade. O desequilíbrio entre característica moral e contexto é preocupante, pois leva-nos a questionar o quanto estes estudantes se veem impotentes diante de um contexto de "guerra" ou de um jogo ao qual só lhes resta adaptar às regras (CALDAS e TONELLI, 2000; KOHLBERG e HERSH, 1977; SENNETT, 2007; WOOD Jr. e PAES DE PAULA, 2001), distanciando-se da posição de sujeitos com autonomia e capacidade de transformação (BOJE e AL-ARKOUBI, 2009; FREIRE, 1983; McLAREN, MARTIN, FARAHMANDPUR et al., 2004).

Os estudantes associaram a palavra indutora administrador a 63 palavras, predominantemente positivas, e, dentre essas, apenas 13 (20,63\%) foram citadas mais de uma vez. Os estudantes atribuíram ao administrador, um sentido fortemente associado a competências (53), seguido de uma fraca associação com característica moral (12). A palavra indutora organização gerou maior dificuldade de associação por parte dos estudantes. Apenas $6(8,11 \%)$, de um total de 74 palavras, foram citadas mais de uma vez. A palavra indutora organização foi mais fortemente associada com consequências (20); ferramenta (19) e competência (19). A associação entre organização e o seu contexto de atuação (14) foi relativamente baixa. Já a característica moral (7) foi menos lembrada.

Os resultados para as palavras indutoras administrador e organização revelam-se inquietantes. Ser administrador, para os estudantes, pressupõe estar dotado de competências como ser visionário, saber planejar, dirigir, estabelecer parcerias e trabalhar em equipe, ser empreendedor, dentre outras. Ao mesmo tempo, ser administrador não está fortemente associado, para estes estudantes, com julgar e ser julgado, haja vista o baixo número de vezes que administrador está associado com característica moral, consequências e contexto. Tal fato leva-nos a questionar se os estudantes percebem que estão sujeitos ao julgamento dos outros mediante os valores vigentes na sociedade em que vivem e irão exercer sua profissão (BIRD e WATERS, 1989; McCABE, BUTTERFIELD e TREVINO, 2006; FARIA, 2007).

Quando relacionamos os resultados das associações para administrador e organização, percebemos que os estudantes têm dificuldade para lidar com a questão "administrar o quê e para quê?", se eles, afinal, se veem responsáveis pela construção da realidade (FENWICK, 2005; FREIRE, 1983). Todavia, os resultados ensejam também uma interpretação otimista: os estudantes reconhecem a complexidade da organização, por isso o elevado número de associações para a palavra organização. As próximas etapas da pesquisa ajudam a esclarecer melhor essa questão.

A expressão indutora ética organizacional obteve a segunda frequência mais baixa de associações. Apenas 8 $(11,27 \%)$, de um total de 71 palavras, foram citadas mais de uma vez. Para os estudantes, a ética organizacional está fortemente associada às consequências (28), indicada por palavras relacionadas a acionistas e demais stakeholders e problemas sócio-ambientais. Esse resultado revela a disposição dos estudantes em adotar a concepção ética teleológica (ABBAGNANO, 1999; VÀSQUEZ, 2005): a decisão de agir de um modo ou outro é dependente das consequências desse agir. Avaliaremos nas próximas seções o quanto essa decisão envolve as consequências para eles mesmos (egoísta) ou para a maior parte dos outros (utilitarista). Também foram realizadas associações com as demandas do contexto que exigem a moralidade do comportamento organizacional, sugerindo que as razões para o comportamento ético é uma característica desejada, que emerge fora da organização, de fora para dentro. Competência e ferramenta foram, poucas vezes, associadas com a palavra ética organizacional.

Os resultados das associações para a expressão indutora ética organizacional são, em princípio, animadores. Especificamente, em relação ao tipo de compromisso psicossocial dos estudantes com o contexto e os outros, o fato de que eles pensam nas consequências da práxis organizacional (JODELET, 2001). Mas, o número significativo de associações entre ética e contexto traz uma preocupação: agir de forma ética é resultado de um posicionamento crítico e reflexivo, sustentado pela consciência moral, ou simples adequação às exigências de um contexto que é representado como força irresistível que se impõe sobre os indivíduos? (MOSCOVICI, 2007). Essa questão é retomada nas próximas etapas da pesquisa. 


\section{Descrição e análise dos resultados: segunda fase da pesquisa}

$\mathrm{Na}$ segunda etapa deste estudo, nós conduzimos a aplicação do completion test, orientadas pelos pressupostos desenvolvidos por Ramsey, Ibbotson, Bell et al. (2004). Nós apresentamos, aos estudantes, cinco situações noticiadas na mídia impressa. Elas foram projetadas por meio de aparelho data-show. Durante e após a projeção de textos e imagens, os estudantes discutiram em grupo e intergrupos o tema da reportagem. Em seguida, apresentamos a posição dos grupos para as três perguntas propostas para cada tema.

O primeiro tema é a ampliação do prazo de licença-maternidade (Quadro 1). Em outubro de 2007, projeto defendido pela Comissão de Direitos Humanos foi aprovado no Senado: a extensão do período da licençamaternidade de quatro para seis meses. A ampliação se tornou facultativa para as empresas e as funcionárias e a concessão de benefícios fiscais foi o estímulo encontrado para as empresas que adotassem a mudança. Defensores da medida afirmavam que ela geraria a redução dos gastos do governo com doenças no primeiro ano de vida da criança, argumento sustentado em dados mundiais que mostrava o período de afastamento em outros países (por exemplo, Austrália com 52 semanas e EUA com 12 semanas). Os especialistas e representantes empresariais apresentaram argumentos contra ou a favor do aumento do benefício, dependendo do interesse em questão, que pode ser o da mulher, da empresa ou do Estado.

A interpretação de 4 grupos $(1,2,3,5)$, para a Pergunta 1 , mostra uma posição que busca o balanceamento entre os aspectos positivos para as mulheres e os negativos para a empresa. Já os integrantes do grupo 4 enfatizam que o aumento do prazo de licença-maternidade é uma questão que desencadearia escolhas por parte dos administradores que podem ser prejudiciais às mulheres, indicando uma possível subordinação da ética à competitividade. Para o grupo 6, a questão está resolvida: é contra o aumento do benefício, pois julga que seis meses é muito tempo para que a mulher se afaste de sua função na empresa. Ou seja, esse grupo adota uma visão instrumental das pessoas e um posicionamento que pode levar à tomada de decisões em que a ética se subordina à competitividade da organização (GHOSHAL, 2005; MINTZBERG, 2007). Também revela a dificuldade dos estudantes para lidar com diferentes e divergentes interesses (GRIT, 2004).

As respostas para a Pergunta 2, que trata da posição dos especialistas sobre o assunto, mostram uma interpretação curiosa: os estudantes de 4 grupos $(1,3,4,5)$ não expressam "o que pensam", eles apenas reafirmam o que os especialistas dizem. Essa aceitação de ferramentas e ideias do campo da gestão, sem uma reflexão sobre suas consequências, lembra-nos o conceito do "indivíduo SA", discutido por Wood Jr. e Paes de Paula (2001). Somente os estudantes do grupo 2 apresentam posição contrária à lei, ao mesmo tempo, eles propõem que o assunto seja discutido. Os estudantes do grupo 6 rejeitam o aumento do benefício. O que indica que os grupos se posicionam em diferentes estágios do desenvolvimento moral (BAGGIO, 1997; KOHLBERG e HERSH, 1977). 


\section{Quadro 1}

\section{Posicionamento simbólico dos estudantes quanto à licença-maternidade}

\section{Tema 1: ampliação do prazo de licença-maternidade}

Senado amplia a licença-maternidade. Fonte: Folha de S.Paulo, 19 out.2007.

Avança na Câmara licença-maternidade de 6 meses. Fonte: Folha de S.Paulo, 9 nov.2007.

\section{Pergunta 1 - 0 que vocês pensam sobre esta lei?}

\begin{tabular}{|c|l|}
\hline Grupo 1 & Afeta negativamente a empresa. Na perspectiva do empregado é importante \\
\hline Grupo 2 & Do lado social amplia benefícios, para a empresa aumenta custos \\
\hline Grupo 3 & Seria bom, se não fosse prejudicar as mulheres no mercado de trabalho \\
\hline Grupo 4 & Administradores vão avaliar se contratam mulher ou homem. \\
\hline Grupo 5 & Para as mães isto é perfeito. Para a empresa é um entrave muito grande \\
\hline Grupo 6 & Os 4 meses atuais são suficientes e 6 meses são excessivos \\
\hline Pergunta 2 - 0 que vocês pensam sobre os especialistas que se posicionam contra esta lei? \\
\hline Grupo 1 & Concorda que a mulher sofrerá preconceitos com a aprovação desta lei \\
\hline Grupo 2 & Posicionamento válido para gerar discussões \\
\hline Grupo 3 & Concorda que vai afetar o espaço da mulher no mercado de trabalho \\
\hline Grupo 4 & Concorda que a lei terá impacto negativo no mercado de trabalho feminino \\
\hline Grupo 5 & Para os especialistas isto vai gerar desemprego para as mulheres \\
\hline Grupo 6 & Apoia, pois o mercado para o público feminino tende a ficar mais restrito \\
\hline Grupo 1 & Financeiramente e funcionalmente \\
\hline
\end{tabular}




\begin{tabular}{|l|l|}
\hline Grupo 2 & Aumento de custos, mudanças no processo de contratação e discriminação \\
\hline Grupo 3 & Afeta a produção e aumenta os custos para cobrir a licença com a substituição \\
\hline Grupo 4 & A empresa perde por falta de qualificação e conhecimento do substituto \\
\hline Grupo 5 & Afeta os resultados \\
\hline Grupo 6 & A organização precisará contratar um substituto e prepará-lo \\
\hline
\end{tabular}

Fonte: Elaborado pelas autoras

Os resultados das respostas para a Pergunta 3 evidenciam que as respostas dos grupos foram homogêneas quanto ao impacto negativo sobre os custos, funcionamento e, consequentemente, os resultados da organização. Essa homogeneidade é motivo de preocupação, devido à tendência moral dos estudantes em se voltarem para um único aspecto, não refletindo sobre as possíveis vantagens que a lei pode trazer à empresa. Nenhuma menção é feita ao fato de que o vínculo afetivo entre mãe e filho, nos primeiros seis meses de vida deste, evita consequências prejudiciais a longo prazo, como, por exemplo, o afastamento do trabalho em virtude de doenças que poderiam ser evitadas com esse reforço. Também não há reflexão sobre o papel das empresas na melhoria da saúde, do bem-estar e no atendimento de necessidades afetivas de mãe e filho. Neste caso, é ignorada a possibilidade dos aspectos positivos da ampliação da licença maternidade superarem os "tão defendidos" aspectos negativos para a empresa. E, conforme os estudos de Kohlberg, essa questão implica que o debate leve em consideração os direitos universais da pessoa (sexto estágio), próprio de um estágio pós-convencional do desenvolvimento moral (KOHLBERG e HERSH, 1977).

O segundo tema é a presença da mulher na publicidade de cerveja (Quadro 2). As campanhas publicitárias para o verão de janeiro de 2007, das empresas fabricantes de cerveja, continham forte apelo sexual, apesar de os executivos das cervejarias terem se comprometido em evitar esta prática. Os executivos de algumas companhias, além do abuso de cenas com conotação erótica, diálogos com sentido ambíguo e a associação da cerveja com êxito sexual, distribuíram gibis eróticos em uma clara associação à marca. Tanto integrantes do mercado publicitário quanto representantes dos produtores de álcool admitem não respeitar, em parte do material publicitário, o acordo de autorregulamentação publicitária feito em 2003. Os executivos das cervejarias, porém, negam que estejam desrespeitando este acordo.

$\mathrm{O}$ acordo mencionado proibia o uso de material publicitário que promove o aumento ou a quantidade do consumo, permitindo apenas o uso de material para promover a marca. A reportagem que apresentamos aos estudantes inclui a regulamentação da venda e da publicidade de cerveja em outros países. Em uma reportagem, os executivos das cervejarias, em nome das companhias, se acusam por consumo abusivo, afirmam que a campanha da concorrente é antiética, além de incentivar o uso exagerado de bebida alcoólica. 


\section{Quadro 2}

\section{Posicionamento simbólico dos estudantes quanto à publicidade de cerveja}

Tema 2: a presença da mulher na publicidade de cerveja

Cervejarias descumprem veto a erotismo. Fonte: Folha de S. Paulo, 30 jan. 2007.

Cervejarias se acusam por consumo abusivo. Fonte: Folha de S. Paulo, 27 mai. 2007.

\section{Pergunta 1 - 0 que vocês pensam sobre a presença da mulher em publicidade de cerveja?}

\begin{tabular}{|l|l|}
\hline Grupo 1 & Que é uma exploração da imagem feminina associada ao consumo de cerveja \\
\hline Grupo 2 & É a associação de um produto ao desejo do público alvo \\
\hline Grupo 3 & É a banalização da mulher em propagandas de cerveja \\
\hline Grupo 4 & Por ser em nosso país, é normal, é uma questão de marketing \\
\hline Grupo 5 & É algo para atrair os homens \\
\hline Grupo 6 & É uma forma de a organização aumentar as vendas \\
\hline
\end{tabular}

Pergunta 2 - Por que vocês acham que as empresas de cervejas utilizam a mulher em sua publicidade?

\begin{tabular}{|l|l|}
\hline Grupo 1 & Para estimular o consumo de cerveja \\
\hline Grupo 2 & Para atrair o seu público alvo e juntar a sensualidade \\
\hline Grupo 3 & Porque o público alvo é o homem \\
\hline Grupo 4 & Porque a maior parte do público consumidor é masculina \\
\hline Grupo 5 & Porque aumentam as vendas \\
\hline Grupo 6 & Porque homens gostam de mulheres e cerveja \\
\hline & Pergunta 3 - Vocês utilizariam este mesmo tipo de publicidade? Por quê? \\
\hline Grupo 1 & Sim, porque é uma estratégia de marketing que traz resultados \\
\hline
\end{tabular}




\begin{tabular}{|l|l|}
\hline Grupo 2 & Sim, porque as concorrentes utilizam e obtêm sucesso \\
\hline Grupo 3 & Sim, porque o mercado está acostumado com esta atuação \\
\hline Grupo 4 & Sim. Porque aumenta as vendas \\
\hline Grupo 5 & Sim. \\
\hline Grupo 6 & Sim. Porque gera retorno financeiro \\
\hline
\end{tabular}

Fonte: Elaborado pelas autoras

Em relação ao segundo tema, apenas os estudantes do grupo 1 e 3 questionam e indicam posicionamento contrário às ações publicitárias das companhias, enquanto os demais não veem problemas nestas práticas de gestão. A resposta do grupo 4 chama a atenção pela associação feita com a expressão "ética de nosso país", isto é, a subordinação da ética à competitividade é colocada entre as idiossincrasias do Brasil, retirando dos indivíduos, ou seja, de cada um de nós, a responsabilidade por essas idiossincrasias. Nas respostas para a Pergunta 2, os estudantes dos grupos 1 e 5 justificam a necessidade de a empresa ter o aumento do consumo ou das vendas para explicar a utilização da mulher em campanhas publicitárias de cerveja; os demais buscam a justificativa no cliente ou público alvo. Isso mostra que os estudantes representam essa situação com uma visão gerencialista, em que estratégia e performance se sobrepõem à comunidade e questões morais, conforme CME (BOJE e AL-ARKOUBI, 2009; MINGERS, 2000). Também, mostra a fragilidade do compromisso ético dos mesmos com a sociedade, aquele compromisso próprio da existência humana, conforme Freire (1983), que existe somente no engajamento com a realidade e na solidariedade com aqueles que se encontram, na situação concreta, convertidos em "coisas".

Quanto às respostas para a Pergunta 3, todos os estudantes responderam "sim", o que indica que, para esses, os fins justificam os meios, e a ética se subordina à competitividade. No caso das respostas dos grupos 1 e 3 , identificamos a presença do "homem camaleão" (CALDAS e TONELLI, 2000) e do "homem irônico" de Sennett (2007) que se adapta às necessidades do mercado, pois, apesar de entenderem que o uso da mulher em publicidade de cerveja caracteriza exploração e banalização, respectivamente, eles adotariam o mesmo procedimento em busca de melhor desempenho. Os estudantes não parecem dispostos a refletir acerca da violência contida nesses comerciais e da disseminação e perpetuação do estereótipo do que é ser homem e ser mulher. Nem mesmo constatamos uma reflexão para os aspectos mercadológicos dos comerciais que, na melhor das hipóteses, não mostram a mulher como consumidora de cerveja, apenas como produto para consumo. A preocupação em ter a aprovação dos outros corresponde a um nível convencional do desenvolvimento moral (BAGGIO, 1997; KOHLBERG e HERSH, 1977; VASQUEZ, 2005). 
Quadro 3

\section{Posicionamento simbólico dos estudantes quanto ao trabalho no corte da cana}

\section{Tema 3: o uso de trabalho de boias-frias no corte de cana}

Tecnologia faz boia-fria trabalhar mais. Fonte: Folha de S. Paulo, 18 set. 2005.

Blitz em Ribeirão vê aliciamento de boia-fria. Fonte: Folha de S.Paulo, Dinheiro, 20.out.2005.

Pergunta 1 - 0 que vocês pensam sobre 0 aliciamento de boias-frias no corte de cana?

\begin{tabular}{|l|l|}
\hline Grupo 1 & Ruim para a imagem do setor é uma forma antissocial de trabalho \\
\hline Grupo 2 & Ocorre por falta de fiscalização e de oportunidade de estudo \\
\hline Grupo 3 & Totalmente irregular, representa a exploração de mão-de-obra \\
\hline Grupo 4 & É uma vergonha, é necessária a regulamentação \\
\hline Grupo 5 & Um abuso \\
\hline Grupo 6 & É um desrespeito, não concordamos, pois é uma forma de trabalho escravo \\
\hline
\end{tabular}

Pergunta 2 - 0 que vocês pensam sobre o trabalho dos boias-frias no corte de cana?

\begin{tabular}{|l|l|}
\hline Grupo 1 & Desgastante, porém, é uma oportunidade de ingresso no mercado de trabalho \\
\hline Grupo 2 & $\begin{array}{l}\text { Gera renda e desenvolvimento para os trabalhadores (legais) e sofrimento e angústia para os } \\
\text { explorados }\end{array}$ \\
\hline Grupo 3 & É normal, um trabalho temporário \\
\hline Grupo 4 & É sofrido: baixa remuneração, elevado risco de saúde, baixa autoestima \\
\hline Grupo 5 & Sacrificante, péssimas condições de trabalho e escravidão \\
\hline Grupo 6 & É um trabalho normal, desde que respeitadas as normas do código de trabalho da categoria \\
\hline & Pergunta 3 - O que vocês fariam se fossem proprietários de uma usina? \\
\hline Grupo 1 & Mudaríamos a imagem que a sociedade tem da indústria sucroalcooleira \\
\hline
\end{tabular}




\begin{tabular}{|l|l|}
\hline Grupo 2 & Promoveríamos uma semiautomatização e também o uso legal de mão-de-obra do boia-fria. \\
\hline Grupo 3 & Contrataríamos os trabalhadores conforme a lei e ofereceríamos condições adequadas \\
\hline Grupo 4 & Buscaríamos normalizar os aspectos trabalhistas e ofereceríamos condições adequadas \\
\hline Grupo 5 & Formaríamos a mão-de-obra, investiríamos em tecnologia e melhores condições de trabalho \\
\hline Grupo 6 & Daríamos melhores condições de trabalho, equipamentos adequados, carteira assinada \\
\hline
\end{tabular}

Fonte: Elaborado pelas autoras

O terceiro tema é o aliciamento de boias-frias para o trabalho no corte de cana (Quadro 3). No ano de 2005, a mídia brasileira noticiou a morte de 10 trabalhadores boias-frias e, desde então, o assunto recebe espaço em jornais e nos noticiários da TV nacionais e internacionais. As causas das mortes são atribuídas ao excesso de trabalho: para atingir a meta de 10 toneladas/dia, um trabalhador precisa desferir 9.700 golpes de podão. As práticas de aliciamento são comuns em várias regiões do país e trabalhadores são atraídos com promessas que nunca se concretizam. O Ministério Público, representantes do Ministério do Trabalho e representantes da ONU investigaram e confirmaram esses abusos, que foram denunciados pelo sindicato dos trabalhadores. Com o aumento da área plantada, o crescimento da mecanização e o baixo valor pago pelo trabalho, os boias-frias precisam trabalhar mais para obter renda. Os usineiros investigados afirmam não haver irregularidades nos canaviais.

Nas respostas para a Pergunta 1, os integrantes dos grupos 1, 3, 4, 5 e 6 se posicionam mais claramente contra a prática de aliciamento de boias-frias. Os estudantes do grupo 2 se posicionam de maneira implícita: responsabiliza os fiscais, o governo e os trabalhadores. Nas respostas para a Pergunta 2, os estudantes separam o trabalho no corte de cana do aliciamento de boias-frias: o primeiro é normal e o segundo, é imoral. Os estudantes parecem preferir simplificar a questão com esta separação, em um tipo de compartimentalização da moral praticada por subjetividades híbridas (FENWICK, 2005). As respostas para a Pergunta 3 reafirmam essa questão; os integrantes do grupo 1 mostram preocupação com a imagem do setor, e os demais parecem entender que o cumprimento da lei, a melhoria das condições de trabalho e aumento da remuneração são práticas suficientes para evitar o desgaste e o sacrifício do trabalho no corte de cana, apontados na resposta para a Pergunta 2.

Os resultados para esse terceiro tema mostram que, por um processo de ancoragem e de objetivação, os estudantes reconhecem o sofrimento dos trabalhadores, mas demonstram dificuldade em lidar com isso como uma situação moral. Eles preferem representar essa situação como um desafio à imagem da organização que pode ser superado com medidas técnicas e legais, sem refletir sobre a melhor forma de lidar com a questão (SCHWINGEL e CAVEDON, 2004). O posicionamento dos estudantes em relação a esse terceiro tema assemelha-se, ainda, ao que foi verificado no segundo tema. Novamente, evidencia-se a fragilidade do compromisso ético dos estudantes com o mundo e a solidariedade deles para aqueles que, na situação descrita, encontram-se convertidos em "coisas" (FREIRE, 1983). 
Quadro 4

Posicionamento simbólico dos estudantes quanto ao recall de brinquedos

\section{Tema 4: o recall de brinquedos}

Mattel faz recall de 18,6 mi de brinquedos. Fonte: Folha de S. Paulo, 15.ago. 2007.

“Não há brinquedo 100\% seguro”, diz Mattel. Fonte: Folha de S. Paulo, 17. ago. 2007.

Brinquedo que vira "ecstasy" terá recall. Fonte: Folha de S. Paulo, 09 nov. 2007.

Pergunta 1 - Por que esta situação de recall dos brinquedos ocorreu?

\begin{tabular}{|c|c|}
\hline Grupo 1 & Porque os produtores da China não têm preocupação com qualidade \\
\hline Grupo 2 & Devido ao descuido muito grande por parte dos órgãos de fiscalização do país \\
\hline Grupo 3 & Devido à busca de lucro a qualquer preço \\
\hline Grupo 4 & A China produz pensando em quantidade, o problema é das empresas que compram \\
\hline Grupo 5 & Falta de estudo e de precaução em relação aos produtos utilizados \\
\hline Grupo 6 & Devido à qualidade ruim do projeto e dos materiais utilizados \\
\hline \multicolumn{2}{|r|}{ Pergunta 2 - Como isso afeta a organização? } \\
\hline Grupo 1 & Afeta a credibilidade da empresa perante os clientes e a sociedade \\
\hline Grupo 2 & Afeta diretamente a marca da empresa e sua credibilidade no mercado \\
\hline Grupo 3 & Afeta a imagem e a credibilidade da empresa no mercado \\
\hline Grupo 4 & A empresa perde credibilidade e venda \\
\hline Grupo 5 & Afeta moral, financeiramente e a idoneidade da empresa \\
\hline Grupo 6 & Afeta a imagem e afeta as vendas \\
\hline
\end{tabular}




\begin{tabular}{|l|l|}
\hline \multicolumn{2}{|c|}{ Pergunta 3 - O que vocês teriam feito ao constatarem o problema? } \\
\hline Grupo 1 & Comprovaríamos que o erro foi de todos os envolvidos e pediríamos desculpa \\
\hline Grupo 2 & Pediríamos desculpas e daríamos atenção especial aos clientes \\
\hline Grupo 3 & Assumiríamos totalmente a responsabilidade pela situação \\
\hline Grupo 4 & Recolheríamos os brinquedos que estão no mercado e divulgaríamos o ocorrido \\
\hline Grupo 5 & Assumiríamos a responsabilidade e trabalharíamos para melhoria e aceitação do produto \\
\hline Grupo 6 & Isto é caso para demissão do responsável pelo projeto \\
\hline
\end{tabular}

Fonte: Elaborado pelas autoras

O quarto tema é o recall de brinquedos (Quadro 4). Em agosto de 2007, a empresa norte-americana Mattel, maior empresa mundial fabricante de brinquedos, anunciou um recall, o terceiro em um ano, de 18, 6 milhões de brinquedos: bonecas, carrinhos e acessórios. $\mathrm{O}$ excesso de chumbo na tinta utilizada em um brinquedo e o uso de acessórios muito pequenos que se desprendem são alguns dos motivos para o recall. Os produtos eram fabricados na China. Inicialmente, os executivos da empresa responsabilizaram os fornecedores chineses, o que causou crise diplomática; depois, afirmaram tratar-se de problema no projeto.

No Brasil, muitas críticas foram dirigidas à empresa pela demora em retirar os produtos das lojas. Em outro caso, ocorrido em novembro de 2007, um teste no brinquedo Aqua Dots (importado pela Long Jump) identificou graves problemas com uma substância presente na composição das bolinhas coloridas do brinquedo. Quando as bolinhas são molhadas para serem grudadas umas nas outras, a referida substância se transforma em outra substância semelhante a uma droga conhecida como "ecstasy líquido" que, se ingerida, pode causar a morte. Este produto também havia sido fabricado na China.

Em relação ao quarto tema, os estudantes dos grupos 1 e 4 se posicionam transferindo responsabilidade; os integrantes do grupo 1 afirmam que a China é a causadora do problema, enquanto que os do grupo 2 responsabilizam os órgãos de fiscalização. Entretanto, a maioria acredita que a ocorrência do recall é responsabilidade das empresas, grupos 3, 4, 5 e 6 . Todos os estudantes concordam que a realização deste tipo de recall tem impactos negativos para a organização.

Quanto ao modo como os estudantes lidariam com esta situação, nas respostas para a Pergunta 3, eles falam em pedir desculpas e assumir a responsabilidade; os integrantes do grupo 1 querem dividir a responsabilidade e os estudantes do grupo 6 simplificam a questão, culpando o responsável pelo projeto. Neste caso, apresentam-se dois problemas morais: a mentira e a simplificação para evitar assumir responsabilidades. Na resposta à Pergunta 3, a tentativa da Matell de culpar os fornecedores chineses não foi criticada. O que indica a baixa disposição dos estudantes para se engajar e liderar transformações (FENWICK, 2005), agir de forma crítica (BOJE e AL-ARKOUBI, 2009; MINGERS, 2000) ou orientar-se por princípios morais que promovam o senso ético e a cidadania em um nível pós-convencional do desenvolvimento moral (BIAGGIO, 1997; KOLHBERG e HERSH, 1977). 
O quinto tema é o episódio conhecido como "a fraude do leite" (Quadro 5). Em outubro de 2007, duas cooperativas foram acusadas de adulterar o leite longa vida integral para aumentar o prazo de conservação e o volume. Os fiscais encontraram a presença de soda cáustica, água oxigenada e citrato de sódio nos produtos. As cooperativas eram fornecedoras de algumas empresas de renome no Brasil, o que gerou grande preocupação da população em relação a este produto. $\mathrm{O}$ fato chamou a atenção para as falhas nos processos de fiscalização da produção de leite e derivados no país. Como consequências, caixas de leite foram recolhidas do mercado, pessoas envolvidas foram presas e houve redução do volume de vendas das empresas.

Os estudantes do grupo 1, 2 e 6 explicam a situação da fraude do leite como algo provocado pelos clientes, pelos concorrentes e pela falta de fiscalização, respectivamente. Tal fato lembra o que Ghoshal (2005) chama de "determinismo de forças externas", ou seja, os administradores justificam suas decisões e ações como reação a estas forças. Também mostra a dificuldade para humanizar as questões: falar de interesses e motivos de quem, e para quê. Os integrantes dos grupos 3 e 4 apontam problemas morais: ambição e falta de ética. Em relação à Pergunta 2, todos veem mais de um responsável pela situação proposta, o que pode sinalizar para a capacidade de analisar a situação de uma forma mais ampla, ou uma forma de dividir responsabilidades, esta última já indicada na resposta à Pergunta 1.

Em relação ao tema "a fraude do leite", todos os estudantes concordam que esta situação afeta negativamente as próprias cooperativas que praticaram a fraude. Nós analisamos com preocupação a resposta dos estudantes do grupo 5, que parecem acreditar que só é ruim para a empresa se a fraude for descoberta. Neste caso, está presente o que Bird e Waters (1989) descreveram como "a moral muda" dos administradores, porém de forma mais alarmante: os gestores não apenas evitam falar sobre questões morais, mas parecem não estar dispostos a refletir sobre tais questões.

Para concluir a análise desta etapa do estudo, lembramos que a Pergunta 1 e a Pergunta 2 foram formuladas visando identificar como os estudantes representam cada tema em condições específicas de tempo e espaço (MOSCOVICI e MARKOVÁ, 1998). Para a Pergunta 1, as respostas, em sua maioria, evidenciam, claramente, uma situação paradoxal, especialmente no tema 1; nos temas 2 e 5, as respostas variam entre uma justificativa para ser competitiva e uma visão do caráter explorador da empresa. Nos temas 3 e 4, as manifestações evidenciam, em sua maioria, a indignação moral dos estudantes.

\section{Quadro 5}

\section{Posicionamento simbólico dos estudantes quanto à adulteração do leite}

\section{Tema 5: a "fraude do leite"}

Laudo de laboratório federal aponta água oxigenada em leite cru da Casmil. Fonte: Folha de S.Paulo, 26 out. 2007.

1/3 do leite brasileiro não passa por fiscalização. Fonte: Folha de S. Paulo, 04 nov. 2007.

Pergunta 1 - Por que vocês acham que esta situação ocorreu?

Grupo 1 Os clientes forçam as empresas a buscarem produtos mais duráveis, além da busca de maior lucratividade por parte das empresas. 


\begin{tabular}{|c|c|}
\hline Grupo 2 & Foi a forma adotada por alguns produtores para enfrentar as grandes empresas. \\
\hline Grupo 3 & Devido à ambição, busca por lucro e corrupção \\
\hline Grupo 4 & Por falta de ética dos responsáveis pela empresa, que não precisa disto para ter lucro \\
\hline Grupo 5 & Para mascarar produtos de péssima qualidade \\
\hline Grupo 6 & Devido à busca de lucro e às falhas de fiscalização \\
\hline \multicolumn{2}{|r|}{ Pergunta 2 - De quem é a responsabilidade? } \\
\hline Grupo 1 & De todos os envolvidos, principalmente do governo \\
\hline Grupo 2 & A responsabilidade é de todos os envolvidos \\
\hline Grupo 3 & Do governo e do gestor da organização \\
\hline Grupo 4 & De todas as pessoas envolvidas, principalmente dos donos da empresa \\
\hline Grupo 5 & Do fabricante e da falta de fiscalização nos processos \\
\hline Grupo 6 & Do processo de qualidade da empresa e da fiscalização governamental \\
\hline \multicolumn{2}{|r|}{ Pergunta 3 - Como isso afeta a organização? } \\
\hline Grupo 1 & Afeta a credibilidade da empresas e do setor de forma geral \\
\hline Grupo 2 & $\begin{array}{l}\text { Afeta a imagem do produto, a credibilidade da empresa, as vendas e pode levar à extinção de } \\
\text { algumas empresas. }\end{array}$ \\
\hline Grupo 3 & Gera perda de credibilidade e confiança e a queda das vendas \\
\hline Grupo 4 & Afeta principalmente a imagem da empresa e além de todo o setor de leite \\
\hline Grupo 5 & Quando isto é descoberto seu prejuízo é incalculável \\
\hline Grupo 6 & Consumidores e fornecedores perdem a confiança na marca e ocorre redução de lucro \\
\hline
\end{tabular}

Fonte: Elaborado pelas autoras 
As respostas à Pergunta 2 evidenciam tanto uma justificativa para a subordinação da ética à competitividade, como uma reprovação para essas ações. Nos temas 1 e 2 , as respostas enfatizam as justificativas para as escolhas da empresa; já no tema 3 , as respostas variam entre a aceitação, conformação e rejeição à subordinação da ética à competitividade. No tema 4, é evidente que os estudantes reconhecem que a negligência da empresa é prejudicial a sua imagem e aos seus resultados; no tema 5, os estudantes parecem não reconhecer que os executivos da organização têm responsabilidade pelo ocorrido, o que seria condizente com estágios pós-convencionais de consciência e desenvolvimento moral (BIAGGIO, 1997; KOLHBERG e HERSH, 1977).

Quanto à Pergunta 3, diretamente relacionada ao modo como os estudantes se posicionam frente ao paradoxo aqui analisado, as respostas para o tema 1 e 2 indicam um posicionamento a favor da competitividade; já os temas 3 e 4 receberam respostas que evidenciam um posicionamento contrário, ou seja, a favor da ética. Por último, no tema 5 , as respostas indicam, também, um posicionamento a favor da ética, pois os estudantes reconhecem as consequências danosas às quais as empresas estão sujeitas.

Ainda, as respostas evidenciam contradições entre as representações dos estudantes e o posicionamento adotado por eles. Como exemplo, observamos as respostas dos integrantes do grupo 1, para o tema 4: a causa do recall foi atribuída aos produtores chineses, eximindo a empresa de qualquer culpa. Porém, o grupo reconhece que isso gera impactos negativos para a empresa, por esse motivo, eles assumiriam a responsabilidade dos fatos para diminuir esses impactos negativos. Além dessa, outra contradição está no fato de, mesmo reconhecendo que algumas decisões e atitudes ferem a ética e conduzem a uma banalização da violência e do mal-estar, os estudantes declaram que adotariam tais atitudes. Outro exemplo de contradição está nas respostas dos integrantes do Grupo 3 para o tema 2: os estudantes admitem que a publicidade de cerveja estimule a banalização da mulher, ainda assim, eles afirmam que utilizariam esse tipo de publicidade, pois "o mercado está acostumado com esta atuação". Justificativa que corrobora a tendência dos estudantes para assumirem posicionamentos orientados pela "flexibilidade moral" (MCCABE, BUTTERFIELD e TREVIÑO, 2006).

As contradições entre representação e comportamento dos estudantes ocorrem em diferentes momentos (O'FALLON e BUTTERFIELD, 2005): ao identificarem e interpretarem as situações e a natureza da questão moral em cada caso; ao fazerem o julgamento e decidirem sobre qual o curso de ação seria moralmente correto em cada situação; ao priorizarem outros valores, por exemplo, a competitividade e a vantagem competitiva, ao invés de princípios morais abstratos e universais (dignidade da pessoa, igualdade, justiça); ao se manifestarem sobre a execução e implementação de práticas de gestão aceitando e relativizando o autoritarismo, a exploração, a transformação das pessoas em coisas.

\section{Descrição e análise dos resultados: terceira fase da pesquisa}

Na terceira e última etapa desse estudo, nós solicitamos aos estudantes que, ainda em grupos, fizessem um desenho que representasse a relação entre ética e competitividade. Após a confecção do desenho, o grupo deveria descrever sucintamente, por escrito, a representação que havia produzido. A seguir, apresentamos os desenhos-tema de três grupos e discutimos os resultados dessa etapa da pesquisa.

Os integrantes do grupo 2 (Figura 1) representam a competitividade como luta e desafio (conforme figura de dois dinossauros) em que se buscam novos mercados e melhores resultados. Para ser bem sucedido, é preciso "sair na frente" e conquistar os clientes, esses irão fazer as suas escolhas e, com isso, determinarão o sucesso ou o fracasso da organização. As metas e objetivos traçados devem ser buscados com verdade e responsabilidade (a foto de Nelson Mandela representa isto, conforme os estudantes desse grupo). Todavia, o grupo também representa a competição como um jogo em que "podemos escolher ser ético ou não". Nesse jogo cada um (empresa, clientes, concorrentes) busca se posicionar e age considerando o que os demais estão 
fazendo. A representação visual da relação entre ética e competitividade como "luta" e "jogo" confirma os resultados da primeira etapa, quando estas duas palavras foram associadas à palavra indutora competitividade.

No desenho-tema do grupo 3 (Figura 2), a relação entre ética e competitividade é representada por meio de referências à indústria automobilística, pelo uso de tecnologias sofisticadas e os benefícios que o automóvel oferece; pouco se fala do papel dessa indústria nos problemas ambientais. Os estudantes representam as empresas que eles percebem ser éticas e competitivas, nesse caso, uma empresa do setor de higiene e cosméticos: a Natura, que investe fortemente na associação da imagem da organização com o meio ambiente. Para esses estudantes, a competitividade está relacionada com "garra" e vontade de vencer e com aquisição de conhecimento. Embora esse grupo enfatize a importância das questões morais, ambientais e sociais, isso ocorre por meio de uma visão idealizada do comportamento ético. A representação do grupo 3 é adaptada ao politicamente correto, sem ousadia e criatividade no entendimento da relação entre ética e competitividade.

Os integrantes do grupo 5 (Figura 3) representaram a relação entre ética e competitividade pela ideia de oposição e de separação. De um lado, o bem: competição com responsabilidade, respeito, fidelidade e transparência. De outro lado, o mal: corrupção, brigas e desonestidade. Nós identificamos a dificuldade deste grupo para representar a ética e a competividade como "mistura" ou "complexidade". Na representação do grupo 5, a relação entre ética e competitividade está assentada na simplificação: é uma questão de escolher entre o bem e o mal. Essa simplificação também está presente na justificativa ou explicação do desenho: é preciso buscar a ética e a competitividade com "profissionalismo" e "caráter", caso contrário os resultados podem ser trágicos.

Figura 1

\section{Desenho-tema do Grupo 2}

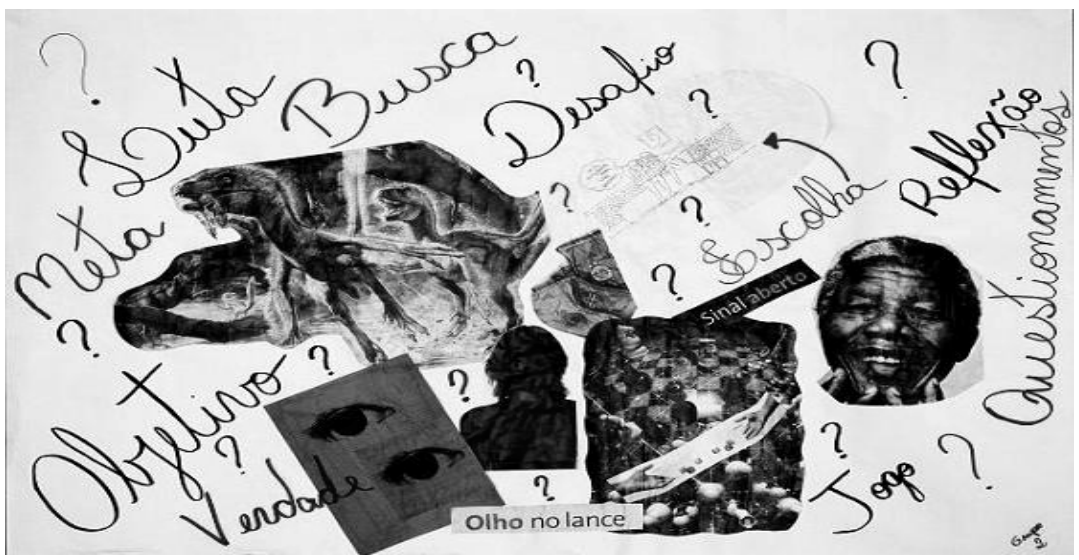

Fonte: foto tirada pelas autoras do desenho-tema do grupo 2 
Figura 2

\section{Desenho-tema do Grupo 3}
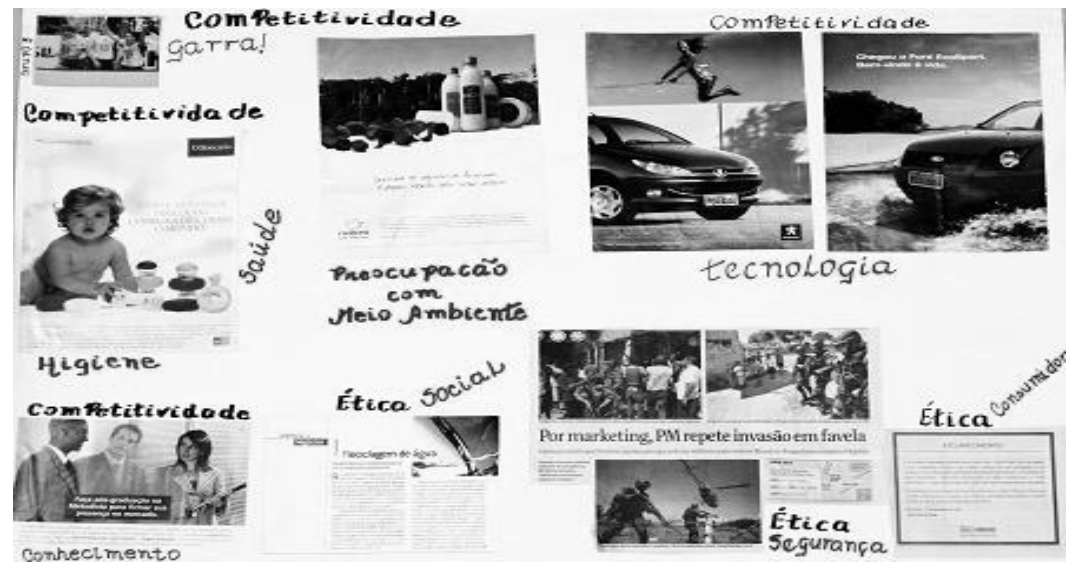

Fonte: foto tirada pelas autoras do desenho-tema do grupo 3

Figura 3

\section{Desenho-tema do Grupo 5}

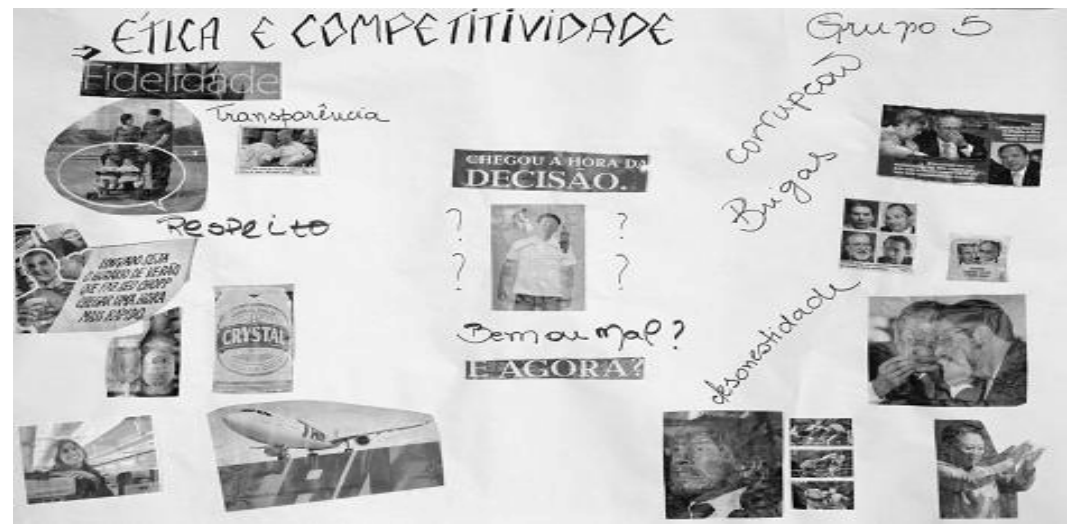

Fonte: foto tirada pelas autoras do desenho-tema do grupo 5

Nos demais cartazes a preocupação com a verdade também é representada. Os integrantes do grupo 6 utilizam a figura de "pinóquio" e afirmam que é necessário aprender a empreender com ética e responsabilidade. No cartaz do grupo 1, os estudantes utilizam as duas faces do papel: de um lado, a representação da ética; de outro, a da competitividade. O que revela que, para os estudantes, ética e competitividade são campos cujas fronteiras podem ser clara e facilmente traçadas.

Essa posição confirma que os mitos sobre a ética em gestão (TREVIÑO e BROWN, 2004) influenciam as representações sociais dos estudantes, pois eles consideram que, para se comportarem de modo ético, basta se afastarem daquilo que "cheira mal" ou que o exercício ético da liderança depende basicamente da integridade dos líderes. O referido posicionamento confirma, ainda, as críticas de Marnburg (2001) à perspectiva cognitiva e à abordagem dos estágios de desenvolvimento moral, pois mostram a fragilidade da 
relação entre julgamento moral, atitudes éticas e comportamento em face da tomada de decisão. Enfim, mesmo sob críticas, os resultados mostram uma fixação moral em estágios pré-convencionais e convencionais do desenvolvimento moral (BAGGIO, 1997; KOHLBERG e HERSH, 1977), visto que a preocupação com a moralidade está estreitamente relacionada com consequências para o gestor ou para a organização, e, menos, devido à consciência moral de princípios e valores universais.

\section{Considerações finais}

Em diferentes momentos, durante debates promovidos em sala de aula com estudantes de graduação em Administração, inquietamo-nos e preocupamo-nos com o posicionamento desses futuros gestores para situações em que ética e competitividade estavam presentes de modo paradoxal. Isso nos estimulou a analisar de forma mais estruturada o que os levava a adotar tais posições. Optamos por desenvolver diversas atividades com um grupo de estudantes que havia terminado de cursar a disciplina de estratégia, ministrada naquele semestre para o $7^{\circ}$ e o $8^{\circ}$ períodos.

As atividades que realizamos com esses estudantes foram descritas e analisadas na seção anterior, a seguir nós enfatizamos as implicações destes resultados.

\section{Implicações do estudo}

As representações que os estudantes constroem do administrador, da administração e da organização orientaos a se posicionarem de modo ambíguo e contraditório em situações que envolvem a ética e a competitividade de modo paradoxal. Nós identificamos, a seguir, cinco posicionamentos e a respectiva representação social que os sustentam.

O primeiro posicionamento é o da simplificação. Esse, ao invés de reconhecer a complexidade das situações de gestão, devido à interdependência de diversos interesses, valores, identidades e expectativas, orienta-se pela representação da administração como um conjunto de decisões - simples decisões de gestão. Essa simplificação (re)apresenta a escolha entre o certo e o errado de forma superficial, pois requer pouca atenção para as consequências das decisões gerenciais para as outras pessoas, o meio ambiente e a própria sobrevivência do empreendimento no longo prazo.

O segundo posicionamento é o da instrumentalidade. A disposição para agir de modo racionalizante revela a preferência pela representação dos problemas morais como mera avaliação e escolha entre o custo-benefício das soluções. Isso significa que os estudantes categorizam essas soluções de acordo com a sua contribuição para a competitividade dos negócios. Também explica a adoção das soluções da moda ou de práticas de gestão já consagradas, ainda que se discorde delas. Essa orientação pela instrumentalidade leva os estudantes a aceitarem a ideia de que toda decisão gerencial gera externalidades e não é possível conduzir um negócio tentando evitá-las a todo instante.

O terceiro posicionamento é aquele do "bom garoto" e da "boa garota", diz respeito à reduzida disposição para realizar a reflexão e a crítica. A representação que orienta esse posicionamento vem do seu oposto: as consequências de se assumir a atitude do gestor-questionador das crenças, valores e procedimentos estabelecidos nas organizações e na indústria. Os estudantes entendem que as empresas não estão abertas para a crítica. Eles discordam de determinadas práticas que as organizações atualmente utilizam, mas se sentem mais seguros repetindo procedimentos e práticas, adotando o comportamento do "bom garoto", ao invés de correr riscos em busca de soluções criativas, inovadoras e inusitadas para os paradoxos e dilemas de gestão. O gestor de sucesso é representado como aquele que se deixa dominar pelas noções de estratégia, competência e controle, de modo totalizante. 
O terceiro posicionamento é o da transferência. Esse diz respeito ao grau de disposição para assumir a responsabilidade pela solução dos problemas morais. Há uma forte tendência dos estudantes para transferir para os outros o papel que eles deveriam assumir na construção da realidade moral: o fornecedor, sem refletir que a empresa escolheu esse fornecedor, o que implica em corresponsabilidade; o concorrente, ao justificarem que, se os concorrentes fazem, então eles precisam fazer também, senão perderão competitividade; e o governo, se este não fiscaliza, dá liberdade para as empresas escolherem entre o "certo ou errado". O administrador e as organizações não são representados como parte inseparável da realidade mais ampla, mas como uma realidade à parte, um outro mundo. Não se ver como construtor da realidade $\mathrm{e}$ não assumir o papel moral que a profissão exige nos parece um dos problemas mais graves dessas representações.

O quarto posicionamento é o do fatalismo. Esses futuros gestores, ao se posicionarem de forma submissa aos requerimentos do capital, podem vir a submeter, além dos seus próprios valores e interesses, aqueles de outras pessoas e o futuro do meio ambiente a esses mesmos requerimentos. As forças do mercado são representadas como entes autônomos que desafiam os gestores a agirem de forma eficiente e estratégica e, também, se adaptarem às regras do jogo. O mercado acionário e a concorrência são representados como entes com poder desproporcional e com vontade própria. $\mathrm{O}$ administrador tem pouca margem para suas escolhas e ação, visto que este processo de personificação gera comportamentos tímidos e impede que o desenvolvimento moral ultrapasse os níveis pré-convencionais e convencionais.

O quinto posicionamento é o da atomização. A relação entre ética e competitividade é representada de maneira a-histórica, não-dialética e fragmentada: ao invés da dinâmica do processo, pensa-se em situações e fatos; ao invés de responsabilidade coletiva, pensa-se em escolhas individuais; ao invés de problemas sistêmicos e estruturais, pensa-se em indivíduos que decidem. As inquietações humanas, os problemas sociopolíticos da comunidade e as demandas ambientais com as quais os gestores precisam lidar cotidianamente não são representados como um todo integrado e dinâmico, mas de maneira pontual, à medida que elas são vistas como ameaças ou oportunidades para os negócios.

\section{Limites do estudo}

Na condução das atividades com os estudantes, nós utilizamos três técnicas projetivas que se mostraram adequadas e ricas por revelarem que os estudantes têm dificuldade para se posicionarem e refletirem criticamente sobre situações que envolvem a ética e a competitividade de forma paradoxal. Todavia, esses resultados foram obtidos com um grupo de 27 estudantes do ensino superior de administração de uma universidade particular. Trata-se de uma instituição de ensino localizada no interior do país, o que torna interessante a ampliação da pesquisa para outros públicos.

$\mathrm{Na}$ coleta dos dados e na análise dos resultados, nós buscamos o diálogo entre duas abordagens que, tradicionalmente, se desenvolveram como campos separados: a Critical Management Education e a Teoria das Representações Sociais. Em nosso estudo, evidenciamos a possibilidade de diálogo entre essas duas abordagens, porém outras pesquisas são necessárias para reafirmar ou questionar as contribuições desse diálogo.

A sala de aula foi o espaço em que realizamos as atividades com os estudantes; a relação aluno-professor, portanto, pode ter influenciado as respostas dos estudantes. Por isso, pesquisas que se desenvolvam em outros espaços podem ampliar os posicionamentos que nós examinamos, considerando apenas o espaço da sala de aula.

Finalmente os resultados desse estudo mostram que professores e instituições de ensino têm papel decisivo na construção das representações sociais que orientam o posicionamento dos estudantes para situações em que a ética e a competitividade estão presentes de maneira paradoxal. Além do gestor como agente moral, o 
que está em pauta aqui é o próprio papel da gestão contemporânea no atual contexto social e político e na construção da realidade.

\section{Referências}

ABBAGNANO, N. Dicionário de Filosofia. São Paulo: Martins Fontes, 1999.

ADLER, P. Corporate scandals: It's time for reflection in business schools. Academy of Management Executive, v. 18, n. 3, p. 148-150, 2002.

ALBAUM, G; PETERSON, R. Ethical attitudes of future business leaders: Do they vary by gender and religiosity? Business and Society, v. 45, n. 3, p. 300-321, 2006.

ARRUDA, M. C. C.; WHITAKER, M. do C.; RAMOS, J. M. R. Fundamentos da ética empresarial e econômica. São Paulo: Atlas, 2001.

BARDIN, L. Análise de conteúdo. Lisboa: Edições 70, 1988.

BAUER, M.W.; GASKELL, G. Towards a Paradigm for Research on Social Representations. Journal for the Theory of Social Behavior, v. 29, n. 2, p. 163-186, 1999.

BIAGGIO, A. M. B. Kohlberg e a "Comunidade justa": promovendo o senso ético e a cidadania na escola. Psicologia: Reflexão e Crítica [on line], v.10, n.1, p. 47-69, 1997. Disponível em: <http://www.scielo.br/scielo.php?pid=S010279721997000100005\&script=sci_arttext $>$. Acesso em: 21 mar. 2010.

BIRD, F.B; WATERS, J.A. The Moral Muteness of Managers. California Management Review, v.32, n.1, p.73-88, 1989.

BODY, C. Projective techniques in market research: valueless subjectivity or insightful reality? International Journal of Market Research, v. 47 n. 3, p. 239-254, 2005.

BOJE, D. M.; AL-ARKOUBI, K. Critical Management Education beyond the siege. In. ARMSTRONG, S. J.; FUKAMI, C. V. (Eds.) The Sage Handbook of Management Learning, Education and Development [p. 104-125]. Sage Publications, 2009.

CALDAS, M. P.; TONELLI, M. J. O homem camaleão e os modismos gerenciais. In. MOTTA, F. C. P.; FREITAS, M. E. Vida Psíquica e Organização [p. 130-147]. Rio de Janeiro: FGV. 2000.

CALTON, J. M.; PAYNE, S. Coping with paradox: multistakeholder learning dialogue as a pluralist sensemaking process for addressing messy problems. Business and Society, v. 42, n. 1, p. 7-42, 2003.

CARRIERI, A. P.; LEITE DA SILVA, A. R.; JUNQUILHO, G. S. O fazer estratégia na gestão como prática social: articulações entre representações sociais, estratégias e táticas cotidianas na organização. In. Encontro Nacional da Associação Nacional dos Programas de Pós-graduação em Administração, 32, Rio de Janeiro, 2008. Anais ...[CDROM].

CARVAlHO, J. M. de (Org.). Problemas e teorias da ética contemporânea. Porto Alegre: Edipucrs, 2004.

CATTERALL, M. ; IBBOTSON, P. Using projective techniques in education research. British Educational Research Journal, v. 26, n. 2, p. 245-256, 2000.

CAVEDON, N. R.; FERRAZ, D. L. da S. Representações sociais e estratégia em pequenos comércios. Fundação Getúlio Vargas: RAE-eletrônica, Revista de Administração de Empresas, v. 4, n. 1, 2005. 
CAVEDON, N. R.; PIRES, R. P. "O pão nosso de cada dia": as representações sociais sobre a vida familiar e profissional dos trabalhadores na indústria da panificação. PUC Minas: E \& G, Economia e Gestão, v. 6, n. 12, p. 1538, 2006.

CHANLAT, J-F. Ciências Sociais e Management. São Paulo: Atlas, 2000.

CHRISTENSEN, S. L; KOHLS, H. Ethical decision making in times of organizational crises: a framework for analysis. Business and Society, v. 42, n. 3, p. 328-358, 2003.

CUNLIFFE, A. L. Reflexive Dialogical Practice in Management Learning. Management Learning, v. 33, n.1, p.35-61, 2002.

CURRIE, G.; KNIGHTS, D. Reflecting on a Critical Pedagogy in MBA Education. Management Learning, v. 34, n.1, p. 27-49, 2003.

DAVEL, E.;VERGARA, S. C.; GHADIRI, D. P. Administração com arte. São Paulo, Atlas, 2007.

DE PAUlA, A. P. P.; RODRIGUES, M. A. Pedagogia crítica no ensino da administração: desafios e possibilidades. Revista de Administração de Empresas, Fundação Getúlio Vargas, v. 46, Ed. Especial Minas Gerais, p. 10-22, 2006.

DUVEEN, G. Introdução: O poder das ideias. In. MOSCOVICI, S. Representações sociais: investigações em Psicologia Social [p. 7-28]. Petrópolis, RJ: Vozes, 2007.

FARIA, J. H. Economia política do poder: fundamentos. Curitiba: Juruá, 2007.

FARR, F. Collective to Social Representations: Aller et Retour. Culture \& Psychology, v. 4, n.3, p. 275-296, 1998.

FARR, R. M. As raízes da Psicologia Social moderna. Petrópolis, RJ: Vozes, 1996.

FENWICK, T. Ethical Dilemmas of Critical Management Education: within classroom and beyond. Management Learning, v. 36, n.1, p. 31-48, 2005.

FRAM, E.H.; CIBOTTI, E. The shopping list studies and Projective Techniques: a 40 year view. Marketing Research: Management \& Applications, v. 3, n. 4, p. 14-23, 2000.

FREIRE, P. Pedagogia do Oprimido. Rio de Janeiro: Paz e Terra, 1970.

Educação e mudança. Rio de Janeiro: Paz e Terra, 1983.

. Pedagogia da Esperança: um reencontro com a pedagogia do oprimido. Rio de Janeiro: Paz e Terra, 1992.

GHOSHAL, S. Bad management theories are destroying good management practices. Academy of Management Learning \& Education, v. 4, n. 1, p. 75-91, 2005.

GIACALONE, R. A.; THOMPSON, K. R. Business ethics and social responsibility education: shifting the worldview. Academy of Management Learning \& Education, v. 5, n. 3, p. 266-277, 2006.

GLADWIN, T.N.; BERDISH, D. MBAs are unprepared for a morally complex future. FINANCIAL TIMES. Disponível em: http://discussions.ft.com/bused/forums/Soapboxforum/mbas-are-unprepared-for-a-morally-complexfuture>. Acesso em: 12 fev.2010.

GRIT, K. Corporate Citizenship: How to strengthen the Social Responsibility of Managers? Journal of Business Ethics, v. 53, n. 2, p. 97-106, 2004.

HBR - HARWARD BUSINESS REVIEW. How To Fix Business Schools. Disponível em: <http://blogs.hbr.org/howo-fix-business-schools/index.php?page=2> Acesso em: 16 fev. 2010a. 
What We've Learned from the MBA Debate. Disponível em:

<http://blogs.hbr.org/hbr/hbreditors/2009/05/wrapping_up_the_debate.html> Acesso em: 16 fev. 2010 b.

HOSMER, L. T. Strategic planning as if ethics mattered. Strategic Management Journal, v. 15, p. 17-34, 1994.

JODELET, D. As representações sociais (Org.). Rio de Janeiro: EDUERJ, 2001.

JONES, T. M. Ethical decision making by individuals in organizations: an issue-contingent model. Academy of Management, v. 16, n. 2, p. 366-395, 1991.

JORNAL FOLHA DE S. PAULO, Retrato da ética no Brasil. Caderno mais!, p. 1-12, 4 out. 2009.

KEARNEY, K. S.; HYLE, A. E. Drawing out emotions: The use of participant-produced drawings in qualitative inquiry. Qualitative Research, v. 4, n. 3, p. 361-382, 2004.

KLEIN, N. Sem Logo. Rio de Janeiro, São Paulo: Record, 2002.

KOHLBERG, L.; HERSH, R. Moral development: A review of theory. Theory into Practice, v. 16, n. 2, Moral Development (Apr., 1977), p. 53-59, 1977.

KOLCK, O. L. V. Interpretação psicológica de desenhos. São Paulo: Pioneira, 1968.

LEWIS, M. W. Exploring paradox: toward a more comprehensive guide. Academy of Management Review, v. 25 , n. 4, p. 760-776, 2000

LILIENFELD, S. O.; WOOD, J.M.; GARB, H.N. The Scientific Status of Projective Techniques. Psychological Science in the Public Interest, v.1, n. 2, p. 27-66, 2000.

MALINOWSKI, C.; BERGER, K. A. Undergraduate student attitudes about hypothetical marketing dilemmas. Journal of Business Ethics, v. 15, n. 5, p. 525-535, 1996.

MARNBURG, E. The questionable use of Moral Development Theory in studies of business ethics: discussion, and empirical findings. Journal of Business Ethics, v. 32, n. 4, p. 275-283, 2001.

MARTIN, A.; MAYNARD, M; DASH, E; SORKIN, R. For Bankers, saying ‘sorry’ has its perils. The New York Times, 01/13/2010. Disponível em:

<http:/query.nytimes.com/gst/fullpage.html?res=9C05E1DD1138F930A25752C0A9669D8B63\&sec=\&spon=\&pagew anted=print $>$. Acesso em: 13 fev. 2010.

MARTYNOV, A. Agents or stewards? Linking managerial behavior and moral development. Journal of Business Ethics, v. 90, p. 239-249, 2009.

McCABE, D. L.; BUTTERFIELD, K. D.; TREVIÑNO, L. K. Academic dishonesty in graduate business programs: prevalence, causes, and proposed action. Academy of Management Learning \& Education, v. 5, n. 3, p. 294-305, 2006.

McLAREN, P.; MARTIN, G; FARAHMANDPUR, R; JARAMILLO, N. Teaching in and against the Empire: Critical Pedagogy as Revolutionary Praxis. Teacher Education Quarterly, v. 31, n. 1, p. 131-153 , 2004.

MELÉ, D. Corporate social responsibility theories. In. CRANE, A.; McWILLIAMS, A.; MATTEN, D.; MOON, J.; SIEGEL, D. S. The Oxford Handbook of Corporate Social Responsibility [p. 47-82]. New York, USA: Oxford University Press Inc., 2008.

MEYER, A. D. Visual data in organizational research. Organization Science, v. 2, n. 2, p. 218-236, 1991.

MINGERS, J. What is it to be critical? Teaching a critical approach to management undergraduates. Management Learning, v. 31, n. 2, p. 219-237, 2000. 
MINTZBERG, H. Produtividade que mata. Revista de Administração de Empresas - RAE Executivo, Fundação Getúlio Vargas, v. 6, n. 6, p. 17-23, 2007.

MOKHIBER, R. Crimes corporativos. São Paulo: Scritta, Página Aberta, 1995.

MOSCOVICI, S. A Representação social da psicanálise. Rio de Janeiro: Jorge Zahar Ed, 1976.

Representações sociais: investigações em psicologia social. Petrópolis, RJ, Vozes, 2007.

O'FALLON, M. J.; BUTTERFIELD, K. D. A review of the empirical ethical decision-making literature: 1996-2003. Journal of Business Ethics, v. 59, n. 4, p. 375-413, 2005.

PERRITON, L. Really useful knowledge? Critical management education in the UK and US. Scandinavian Journal of Management, v. 23, n.1, p. 66-83, 2007.

PFEFFER, J. Why do bad management theories persist? A comment on Ghoshal. Academy of Management Learning \& Education, v. 4, n. 1, p. 96-100, 2005.

PRIEM, R.; SHAFFER, M. Resolving moral dilemmas in business: A multicountry study. Business and Society, v. 40, n. 2, p. 197-219, 2001.

RAMSEY, E.; IBBOTSON, P.; BELL, F.; GRAY, B., A projectives perspective of international "e"-services. Qualitative Market Research: an international journal, v.7, n.1, p.34-47, 2004.

SAMRA-FREDERICKS, D. A Proposal for Developing a Critical Pedagogy in Management from Researching Organizational Members' Everyday Practice. Management Learning, v. 34, n. 3, p. 291-312, 2003.

SCHLEIDGEN, S.; JUNGERT, M. C.; BAUER, R. H. Mission: Impossible? On empricial-normative collaboration in ethical reasoning. Ethical Theory and Moral Practice, v. 13, n. 1, p. 59-71, 2010.

SCHWINGEL, B.; CAVEDON, N. R. As representações sociais dos médicos, enfermeiros e cirurgiões dentistas de equipes de saúde da família sobre educação em saúde. In. MISOCZKY, M. C.; BORDIN, R. (Orgs.) Gestão local em saúde [p. 147-168]. Porto Alegre: DACASA, 2004.

SENNETT, R. A corrosão do caráter: consequências pessoais do trabalho no novo capitalismo. Rio de Janeiro, São Paulo: Record, 2007.

TREVIÑO, L. K. Ethical decision making in organizations: a person-situation interactionist model. Academy of Management Review, v. 11, n. 3, p. 601-617, 1986.

TREVIÑO, L. K.; BROWN, M. Managing to be ethical: debunking five business ethics myths. Academy of Management Executive, v. 18, n. 2, p. 69-81, 2004.

TREVIÑO, L. K.; NELSON, K. A. Managing business ethics: straight talk about how to do it right. New York: John Wiley \& Sons, Inc., 1995.

VÁSQUEZ, A. S. Ética. Rio de Janeiro: Civilização Brasileira, 2005.

VINCE, R. ; BROUSSINE, M. Paradox, defense and attachment: Accessing and working with emotions and relations underlying organizational change. Organization Studies, v. 17, n. 1, p. 1-21, 1996.

VOELKLEIN, C; HOWARTH, C. A review of controversies about social representations Theory: A British Debate. Culture \& Psychology, v. 11, n. 4, p.431-456, 2005.

ZAHRA, S A; PRIEM, R.L.; RASHEED, A.A. The antecedents and consequences of top management fraud. Journal of Management, v. 3, n. 6, p. 803-830, 2005. 
WATERS, J. A.; BIRD, F.; CHANT, P. D. Everyday moral issues experienced by managers. Journal of Business Ethics, v. 5, n. 5, p. 373-384, 1986.

WEBER, J.; McGIVERN, E. A new methodological approach for studying moral reasoning among managers in business settings. Journal of Business Ethics, v. 92, n. 1, p. 149-166, 2010.

WOOD JR., T.; PAES DE PAULA, A. Pop-management. In: Encontro da Associação Nacional de Pós-Graduação e Pesquisa em Administração, 25, Campinas, 2001.CD-ROM. 